\title{
POLYGAMOUS MARRIAGE, MONOGAMOUS DIVORCE
}

\author{
MiCHAEL J. HigdON $\dagger$
}

\begin{abstract}
Could the constitutional right to marry also encompass polygamy? That question, which has long intrigued legal scholars, has taken on even greater significance in the wake of Obergefell v. Hodges. This Article answers that question in a novel way by scrutinizing the practice of plural marriage through the lens of economic game theory, exploring the extreme harms that would befall the state should polygamy become law. More specifically, the Article delves into the ex ante consequences of legalization, not on practicing polygamists (as is typically the focus), but on sequential bigamists - that is, those who never intend to have more than one spouse at any given time but who nonetheless marry more than one person in their lifetime. The Article concludes that the state has a compelling economic interest in limiting marriage to two people. If polygamy were to become the law of the land, states could no longer prohibit bigamy. In turn, separating couples would lose one of the strongest incentives they currently have to choose formal divorce proceedings over the seemingly simpler option of mutual desertion: the threat of criminal charges for bigamy. In essence, a sequential bigamist could then marry multiple times in his lifetime without ever divorcing and, at the same time, without risking a criminal charge of bigamy. Such actions-dubbed "sequential polygamy"-would compromise the state's interest in protecting its citizens from financial harms. After all, divorce proceedings provide the state with an opportunity to intercede into the process, thereby obtaining some assurance that those who are leaving a marriage are not doing so at their financial peril. With the legalization of polygamy, however, bigamy becomes a thing of the past, eroding the state's ability to encourage divorce as a means of safeguarding the health and safety of its citizens. Most concerning is the impact this change would have on those living in poverty-the
\end{abstract}

Copyright (c) 2017 Michael J. Higdon.

$\dagger$ Professor of Law, University of Tennessee College of Law. A special thank you to Teri Dobbins Baxter, Don Leatherman, and Bradley A. Areheart for their invaluable feedback. I am grateful to the University of Tennessee College of Law, particularly Dean Melanie Wilson, for providing generous financial support for this project. 
people likely to be hardest hit by any societal shift away from formal divorce. Finally, any attempts by the state to distinguish between bigamy and polygamy (for example, by permitting plural marriage but only if all spouses consent), would fail to ameliorate the resulting harm to its citizens.

\section{TABLE OF CONTENTS}

Introduction

I. Polygamy: Practice and Prevalence Within the United States ........ 90

II. The Fundamental Right to Marry: A Brief Overview .................... 96

III. The Protective Function of Divorce ...............................................104

A. Protections for Former Spouses .........................................107

1. The Absence of Common Law Divorce ..........................108

2. Review of Settlement Agreements .....................................111

B. Protections for Future Spouses............................................113

1. Subsequent Marriage Presumption.................................115

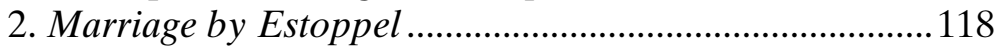

3. Putative Marriage ............................................................. 121

IV. The Ex Ante Costs of Legalizing Polygamy ................................125

A. Legalized Polygamy Undermines the States' Compelling Interest in Promoting Divorce Among Separating

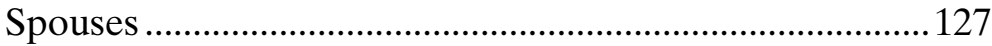

1. Harms to Initial Spouses ..................................................130

2. Harms to Subsequent Spouses ........................................132

B. A Complete Ban is Necessary To Safeguard the States'

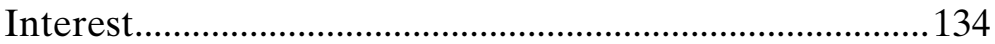

1. Gradual Polygamy with Consent ....................................135

2. Instant and Complete Polygamy ....................................139

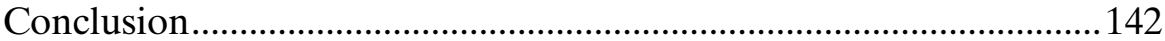

Law often amounts to a substitute for trust in situations too complex or dispersed for trust to arise.

- Ward Farnsworth ${ }^{1}$

\section{INTRODUCTION}

Within the United States, marriage is and always has been limited

1. Ward FARnsworth, The Legal AnAlyst: A TOOLKIT FOR Thinking ABOUT the LAW 103 (2008). 
to two people. ${ }^{2}$ Somewhat ironic, then, is the understanding that every marriage is, in actuality, comprised of three parties - the third being the state. ${ }^{3}$ That the state would play such an involved role should come as little surprise, however, given the state's "interest in preserving the integrity of marriages and in safeguarding family relationships." "That interest is particularly acute when it comes to divorce. As one court aptly explained, "[s]ince marriage is of vital interest to society and the state ... in every divorce suit the state is a third party whose interests take precedence over the private interests of the spouses." ${ }^{5}$ Quite simply, because "[d]ivorce, by its very nature, is likely to result in some social and financial harm to one or both parties," the state is very much concerned with watching out for and protecting those going through the process of marital dissolution. In fact, divorce proceedings are designed and structured primarily to permit the state to oversee the process, thus enabling the state to better "protect each of the parties and their conflicting interests." ${ }^{\prime 7}$ In order to play that crucial role, however, the state must first insure that its citizens elect to end their marriages through formal divorce proceedings, as opposed to the more informal option of simply deserting one another.

It is helpful at the outset to understand how and why the state incentivizes individuals to divorce, particularly since this Article ultimately concludes that legalizing polygamy would undermine the

2. See Homer H. Clark, Jr. \& Ann laquer Estin, Cases and Problems on DOMESTIC RELATIONS 114 (2005) ("It goes without saying that monogamy is the controlling principle of Anglo-American marriage law.").

3. See, e.g., Goodridge v. Dep't of Pub. Health, 798 N.E.2d 941, 954 (Mass. 2003) ("In a real sense, there are three partners to every civil marriage: two willing spouses and an approving State."); Hernandez v. Robles, 855 N.E.2d 1, 13 (N.Y. 2006) (Graffeo, J., concurring) (recognizing that "[t]here are, in effect, three parties to every marriage, the man, the woman and the State." (alteration in original) (quoting Fearon v. Treanor, 5 N.E.2d 815, 816 (1936))); Fricke v. Fricke, 42 N.W.2d 500, 501 (Wis. 1950) ("There are three parties to a marriage contract - the husband, the wife, and the state.")

4. Mark Strasser, Legally Wed: SAME-SEX MARRIAGE AND THE CONSTITUTION 125 (1997).

5. Posner v. Posner, 233 So. 2d 381, 383 (Fla. 1970) (emphasis added); see also Manion v. Manion, 363 A.2d 921, 923 (N.J. Super. Ct. 1976) ("Our Supreme Court has said . . 'in every suit for divorce the State is in fact if not in name a third party having a substantial interest." (quoting In re Backes, 109 A.2d 273, 275 (1954))); Gross v. Gross, 464 N.E.2d 500, 505 (Ohio 1984) (noting that the "state is virtually a party to every marital contract in that it possesses a continuing concern in the financial security of divorced or separated persons").

6. Gale Humphrey Carpenter, Comment, Protecting the Privacy of Divorcing Parties: The Move Toward Pseudonymous Filing, 17 J. AM. ACAD. MATRIM. LAW. 105, 113 (2001).

7. LENARd MARLOW \& S. Richard SAUber, THE HANDBOOK OF DivorCE MEDiATION 89 (1990); see infra Part III. 
state's ability to effectively incentivize that choice. To explain how the state incentivizes this choice, it is helpful to look to the example of the prisoner's dilemma. The prisoner's dilemma is an often-used example of a collective action problem. ${ }^{8}$ The setup is that two prisoners, each suspected of working with the other to commit a serious crime, are isolated from one another and given two choices. The first is to confess to the joint enterprise, and the second is to keep silent. If both prisoners keep silent, each will be sentenced to one year in prison. If both confess, implicating one another, each prisoner will receive a sentence of five years. If, however, one confesses and the other remains silent, the prisoner who confesses will go free while the prisoner who refuses to speak will receive a sentence of ten years.

An interesting dilemma thus presents itself-neither prisoner knows what the other is going to do and, accordingly, when it comes time for each to decide whether to confess or remain silent, it is unclear which action would be most beneficial. The most mutually beneficial option is for both to keep silent, which will result in a sentence of one year for each prisoner; however, if one suspects that the other plans to remain silent, then he would, in turn, be tempted to confess. After all, if he confesses but his partner in crime does not, then he is set free. But if both fall prey to this same temptation and both confess, then they each get five years-four years more than if they had simply kept quiet. ${ }^{9}$

As illustrated by the prisoner's dilemma, failure to cooperate can result (at least from the perspective of the two prisoners) in aggregate waste - a result that, as any legal economist can attest, the law abhors. ${ }^{10}$ For that reason, the law actively seeks to encourage cooperation

8. The prisoner's dilemma is particularly popular within the realm of economic game theory - an area described as "an amalgam of economics, mathematics, and other sciences, the purpose of which is to shed light on strategic interaction." FARNSWORTH, supra note 1, at 101; see also GRAHAM ROMP, GAME THEORY: INTRODUCTION AND APPLICATIONS 1 (1997) ("Game theory is concerned with how rational individuals make decisions when they are mutually interdependent.").

9. Quite a few variations of the prisoner's dilemma exist. See John C. Coffee, Jr., Class Wars: The Dilemma of the Mass Tort Class Action, 95 ColuM. L. ReV. 1343, 1372 n.105 (1995); Russell B. Korobkin \& Thomas S. Ulen, Law and Behavioral Science: Removing the Rationality Assumption from Law and Economics, 88 CALIF. L. REV. 1051, 1138-39 (2000).

10. See Finney Cty. Water Users' Ass'n v. Graham Ditch Co., 1 F.2d 650, 652 (D. Colo. 1924) ("As a general principle, equity abhors waste, and delights to restrain it in a proper case."); Saul Levmore, Explaining Restitution, 71 VA. L. REV. 65, 72 (1985) ("Applying the notion of economic efficiency to tort and contract law often involves a search for the party best able to control a situation: legal liability is imposed to induce that party to minimize waste."). 
between parties to achieve efficient, mutually beneficial results. ${ }^{11}$ The law does this in two ways: by incentivizing ex ante agreements and, for those who need extra motivation to cooperate, by threatening punishment for noncooperation. The hypothetical prisoners in the prisoner's dilemma, for instance, would not have found themselves in that particular quandary had they been permitted to talk with one another ahead of time and make an enforceable agreement not to confess. To avoid this inefficiency, the law encourages ex ante agreement via contracts, ${ }^{12}$ but it simultaneously uses the threat of ex post punishment, like the legal penalties found in tort and criminal law,,$^{13}$ to further encourage cooperation. The theory is that the fear of sanction will provide the requisite motivation to cooperate.

While the law is sometimes used to promote cooperation and defuse prisoner's dilemmas, other times it is used to affirmatively foster new dilemmas in order to steer parties away from cooperation deemed harmful to societal interests. ${ }^{14}$ The focus in discussing the prisoner's dilemma has thus far been on what decision would be most beneficial from the perspective of the two prisoners, but the hypothetical is not quite that simple. The prisoner's dilemma, just like marriage, also involves the interests of a third party, and that third party is the state. After all, the prisoner's dilemma presents a situation in which society would prefer that the parties not cooperate. Indeed, if each prisoner truly is guilty, punishing both with prison sentences would likely be in society's best interest. As a result, the societal benefit of disallowing cooperation between the prisoners heavily outweighs any benefit such cooperation would bring the individual parties.

The law recognizes that cooperation is not always desirable for

11. See, e.g., ERIC A. PoSNER, LAW AND Social Norms 15 (2002) ("The law encourages cooperation in many ways."); Raymond H. Brescia, Trust in the Shadows: Law, Behavior, and Financial Re-Regulation, 57 BUFF. L. REV. 1361, 1405 (2009) ("[L]aw can help encourage the initial cooperative move that is so important for encouraging trusting and cooperative behavior.").

12. See FARNSWORTH, supra note 1, at 102 ("Contracts allow people to limit their options if others will limit their own in return; they give everyone a convenient way to beat prisoner's dilemmas and enjoy the gains that come from cooperation.").

13. Kenneth G. Dau-Schmidt, A Bargaining Analysis of American Labor Law and the Search for Bargaining Equity and Industrial Peace, 91 MICH. L. REV. 419, 494 (1992) (“[T]he law relies both on prohibitions of strategic behavior and on measures designed to encourage the parties to achieve the cooperative solution themselves.").

14. See Gary W. Cox \& Mathew D. McCubbins, Legislative LeViathan: Party GOVERNMENT IN THE HOUSE 84 (2d ed. 2007) ("In many cases, of course, action can be taken to create prisoner's dilemmas. Examples include the District Attorney's separation of the suspects in the original prisoner's dilemma, antitrust laws, and open shop laws."). 
society at large, and in such instances, the law can instead "try to structure their incentives to destroy that possibility." 15 Antitrust laws, for example, target an area of "unwanted cooperation" involving "business rivals who get together in smoky hotel rooms and fix the prices of their wares." 16 Given the harms that would flow from such practices, "[t]he purpose of antitrust laws is to instead force them into separate rooms, figuratively speaking, so they will do the individually rational thing, which is to compete vigorously." 17

In fact, the law is replete with mechanisms that make it rational for individuals to eschew options that might appear more self-serving and instead elect options that ultimately benefit the larger group. ${ }^{18} \mathrm{At}$ the heart of this Article lies one such mechanism: the financial protections provided to divorcing spouses under the law of divorce. To understand how divorce operates in that manner, consider the two options before a married couple who has decided to permanently part ways. They could simply agree to divide their property informally between themselves, go their separate ways, and just pretend as though the marriage never took place. If both remained silent about the fact that they never divorced, it is unlikely that either would ever be penalized or even caught. ${ }^{19}$ Alternatively, they can formally divorce,

15. FARNSWORTH, supra note 1, at 108. Game theory, once again, can help to understand the process of determining which laws will incentivize cooperation and which will prevent it. See, e.g., Farrukh B. Akeem, Sports Related Crime: A Game Theory Approach, in MATCH-FIXING IN INTERNATIONAL SPORTS: EXISTING PROCESSES, LAW ENFORCEMENT AND PREVENTION STRATEgIES 247, 253 (M.R. Haberfeld \& Dale Sheehan eds., 2013) ("Game theory enables the government to predict which laws will encourage cooperation among parties, and also the laws that will disincentivize cooperation.").

16. FARNSWORTH, supra note 1, at 108; see also John K. Setear, Note, Discovery Abuse Under the Federal Rules: Causes and Cures, 92 YALE L.J. 352, 371 n.101 (1982) ("Where a complicated case involves two parties with substantial resources, the Prisoner's Dilemma [sic] is therefore especially acute.").

17. FARNSWORTH, supra note 1, at 108. See generally John Shepard Wiley Jr., Reciprocal Altruism as a Felony: Antitrust and the Prisoner's Dilemma, 86 MICH. L. REV. 1906 (1988) (discussing antitrust laws in the context of the prisoner's dilemma).

18. FARNSWORTH, supra note 1, at 103 ("We're all better off if nobody steals ... than if everyone does; but that may not be enough to get each of us not to do those things when we privately decide for ourselves. Conscience is a help then, but perhaps not as convincing as the threat of coercion."); see also Erin Ann O'Hara \& Douglas Yarn, On Apology and Consilience, 77 WASH. L. REV. 1121, 1130 n.31 (2002) ("The Prisoner's Dilemma disregards ethical considerations; it is simply rational to be selfish in this moral vacuum whenever the temptation to defect exceeds the benefits of cooperation.").

19. See, e.g., ANN LAQuer Estin, DOMESTIC Relationships: A CONTEMPORARY APPROACH 113 (2013) ("[R]ules against bigamy are not enforced very often. Criminal prosecutions are rare,... [and] [o]n the civil side, various doctrines dilute the force of the monogamy principle."); see also infra Part III.B (discussing the civil doctrines designed to 
which entails potentially significant expense, emotional stress, and perhaps even societal stigma. ${ }^{20}$ When presented that way, the choice appears rather simple. The law of domestic relations, however, actively encourages couples to select the more onerous option of formal divorce, and it does so in a number of ways: through property-based incentives and, should those incentives fail, the threat of criminal prosecutions for bigamy.

First are the property-based incentives. Regardless of whatever settlement the parties might informally work out between themselves, each party would likely believe that the formalities and procedures that accompany a court-supervised divorce proceeding could benefit either or both parties. First, hiring a divorce attorney, who is a personal advocate and a family law expert, might result in a more beneficial outcome. $^{21}$ Second, because divorce settlements are ultimately reviewed by courts for fairness, even parties that are not represented by counsel could be awarded a better deal than would be struck outside court. ${ }^{22}$ Finally, even for a wealthier spouse who potentially has more to lose, divorce is nonetheless an attractive option because it provides finality, in that it extinguishes any claim a former spouse would have to property that the wealthier spouse might acquire in the future. ${ }^{23}$ Thus, regardless of the parties' financial interests, the law incentivizes separating couples to pursue formal divorce proceedings.

Such property-based incentives, however, are unlikely to have much influence on those divorcing couples who lack significant marital property. This reduced incentive may explain why poorer individuals, although more likely to separate, are nonetheless less likely to divorce. ${ }^{24}$

ameliorate the harms caused by bigamy).

20. See Elizabeth Brake, Minimizing Marriage: Marriage, Morality, and the LAW 56 (2012) (noting that "marriage is distinguished by the scope of its penalties-legal, economic, social, and moral").

21. See, e.g., Emily S. Taylor Poppe \& Jeffrey J. Rachlinski, Do Lawyers Matter? The Effect of Legal Representation in Civil Disputes, 43 PEPP. L. REV. 881, 922-23 (2016) (summarizing studies that found "that legal representation for a plaintiff was associated with an increase in the odds of an award of alimony or support").

22. See infra Part III.A.2.

23. Alicia Brokars Kelly, The Marital Partnership Pretense and Career Assets: The Ascendency of Self over the Marital Community, 81 B.U. L. REV. 59, 100 (2001) ("[P]roperty acquired after divorce is considered separate property to which an ex-spouse has no claim.").

24. Jesse H. Choper, Consequences of Supreme Court Decisions Upholding Individual Constitutional Rights, 83 MICH. L. REV. 1, 150-51 (1984) ("[A]lthough the bottom economic groups produce the highest separation rates, they also show very low divorce rates, thus giving inferential support to the intuitive conclusion that many poor people who desire a divorce simply cannot afford one.”). 
As one commentator explains, "One not so uncommon American story is that of the man who marries, deserts his wife without judicial dissolution of the marriage, and then takes a new wife." 25 And of particular significance to the state is the fact that " $[\mathrm{t}]$ he story most often occurs within the lower socioeconomic strata of society-the societal group whose widowed women are most apt to become welfare recipients." 26 Thus, the state, in light of its "substantial interest in the economic and social welfare of its members," 27 requires a more practical, non-property-based incentive to more fully incentivize formal divorce.

Criminal law provides such a non-property-based incentive. No person may legally have more than one spouse. ${ }^{28}$ Thus, a married couple who decides to separate must first divorce before either can remarry. Theoretically, either could take a chance and remarry without first getting a divorce, but doing so would expose that person to a potential charge of bigamy. ${ }^{29}$ More importantly, such action would put the subsequent spouse in a precarious financial situation. ${ }^{30}$ Specifically, that person's subsequent "spouse" would be denied the benefits and protections of marriage should the subsequent marriage ultimately be declared bigamous and, thus, void. Indeed, it is because of the states' interest in protecting spouses - both former and subsequent - that the law, predominantly through rules against bigamy, attempts to encourage separating couples to elect divorce. ${ }^{31}$ After all, because divorce proceedings require the participation of the state, divorce actions assist the state in obtaining assurances that its citizens' economic interests are being safeguarded.

25. E. Hunter Taylor, Jr., Repeal of the Presumption of the Validity of Subsequent Marriages: Another Irrational Step Toward Increasing the Welfare Roles, 21 MERCER L. REV. 465, 465 (1970).

26. Id.; see also infra notes 196-98 and accompanying text.

27. Taylor, supra note 25 , at 467 ; see also infra note 38 and accompanying text.

28. See Estin, supra note 19, at 113 ("Monogamy is the controlling principle of AngloAmerican marriage law: a person may have only one spouse at a time."); Taylor, supra note 25, at 467 ("The more direct criminal bigamy prosecution would seem to be the law's most appropriate implement for this purpose.").

29. See Robert L. Maddex, EnCyclopedia of SeXual BeHavior and the LaW 36 (2006) (noting that "[b]igamy is a crime in all states and the District of Columbia, with little variation among these laws"). Further, bigamy is "generally considered a serious crime punished as a felony." Id.

30. See infra Part IV.A.2.

31. See, e.g., Maura Strassberg, The Crime of Polygamy, 12 TEMP. POL. \& CIV. RTS. L. REV. 353, 420 (2003) (characterizing the Model Penal Code's definition of bigamy as, essentially, "the practice of entering into a second purportedly legal marriage without ever legally dissolving an unsuccessful first marriage" (emphasis added)). 
States, of course, do not have unlimited authority when it comes to regulating marriage. Indeed, the Supreme Court has struck down a number of attempts by states to limit access to marriage. ${ }^{32}$ Most recently, the Court ruled in Obergefell v. Hodges ${ }^{33}$ that, under the Due Process Clause of the Fourteenth Amendment, states cannot restrict marriage licenses to opposite-sex couples. ${ }^{34}$ Instead, same-sex couples must be granted access to marriage on the same terms as their oppositesex counterparts. That opinion raises the following question: whether other previously prohibited forms of marriage, including polygamy, must, pursuant to the Fourteenth Amendment, likewise be recognized. ${ }^{35}$ Although currently quite rare in the United States, polygamy nonetheless exists-primarily in certain religious communities and in immigrant communities where polygamy is the traditional way of life. ${ }^{36}$

In analyzing whether there is a constitutional right to enter into a polygamous marriage, scholars and commentators have taken positions on both sides of the argument and have used various rationales to do so. ${ }^{37}$ This Article takes a different approach. Looking at polygamy through the lens of law and economics, this Article concludes that, even if polygamy were included within the fundamental right to marriage, the states nonetheless have a compelling justification for continuing their refusal to recognize plural marriage: their

32. See infra Part II.

33. Obergefell v. Hodges, 135 S. Ct. 2584 (2015).

34. Id. at $2584,2598$.

35. See, e.g., Edward Stein, Plural Marriage, Group Marriage and Immutability in Obergefell v. Hodges and Beyond, 84 UMKC L. REV. 871, 871 (2016); Jonathan E. Amgott, Note, PostWindsor Prospects for Morals Legislation: The Case of Polygamous Immigrants, 26 STAN. L. \& POL'Y REV. 513 passim (2015); Greggary E. Lines, Note, Polymmigration: Immigration Implications and Possibilities Post Brown v. Buhman, 58 ARIZ. L. REV. 477, 478 (2016) (discussing a recent case in which "a polygamous family argued that Obergefell validated their application for a marriage license").

36. See infra Part I.

37. See infra note 83 and accompanying text. One author wrote that:

the right to control the number of persons in a marriage should not receive heightened scrutiny because the fundamental right to marry cannot be extended to a fundamental right to marry multiple persons. Therefore, courts should apply rational basis review to polygamy laws, and the states have more than adequate state interests to meet this level of scrutiny.

Jonathan A. Porter, L'Amour For Four: Polygyny, Polyamory, and the State's Compelling Economic Interest in Normative Monogamy, 64 EMORY L.J. 2093, 2138 (2015); see also Keith E. Sealing, Polygamists Out of the Closet: Statutory and State Constitutional Prohibitions Against Polygamy Are Unconstitutional Under the Free Exercise Clause, 17 GA. ST. U. L. REV. 691, 748 (2001) ("The right to marry is a fundamental right subject to the protection of strict scrutiny analysis, as a result of the close link between the right of marriage and the practice of religion."). 
substantial interest in promoting divorce among separating couples. If the Court were to rule that states could not limit marriages to two people, the consequences would be severe. From a deontological perspective, there would perhaps be fewer difficulties for those who actively and knowingly engage in polygamy.$^{38}$ Under a consequentialist approach, however, the ex ante result of removing prohibitions against polygamy would be that nonpolygamous couples could agree to separate informally and later marry other people without any fear that they might be prosecuted for bigamy - "the criminal law under which polygamy is typically prosecuted" $" 39$-and also without any fear that their latest spouse would be denied the legal protections of marriage. ${ }^{40}$

In other words, legalizing polygamy would eliminate one of the strongest incentives couples currently have to choose formal divorce. The result would be that divorcing couples, just like the prisoners in the prisoner's dilemma, would be even more tempted to cooperate in

38. This conclusion is doubtful. Polygamy would likely create a number of issues, including child custody, property distribution at divorce, and intestate succession. Even more troubling are the concerns about how, in practice, legalized polygamy can become a mechanism for subjugating women. See SHEILA JEFFREYS, MAN's DOMINION: THE RISE OF RELIGION AND THE ECLIPSE OF WOMEN's RIGHTS 151 (2011) ("The harms of polygamy differ as to context, but reports from all forms of the practice, across both multicultural states and states where polygamy is a traditional practice, demonstrate severe harms to women and children.").

39. Claire A. Smearman, Second Wives' Club: Mapping the Impact of Polygamy in the U.S. Immigration Law, 27 BERKELEY J. INT'L L. 382, 383-84 (2009). Just as the law today uses the terms "bigamy" and "polygamy" as interchangeable, so too does this Article. See Marjorie A. Shields, Annotation, Validity of Bigamy and Polygamy Statutes and Constitutional Provisions, 22 A.L.R.6th 1, § 2, at 6 (2007) (“[T]he terms bigamy and polygamy are now used interchangeably."). It should be noted, however, that, in some instances, the law has attempted to use the terms in such a way that they refer to two distinct practices. Under the Model Penal Code, for instance, bigamy occurs when a "married person ... contracts or purports to contract another marriage." MODEL PENAL CODE $§ 230.1$ (1) (AM. LAW INST. 1980). In contrast, polygamy occurs if a person "marries or cohabits with more than one spouse at a time in purported exercise of the right of plural marriage." Id. § 230.1(2).

40. In taking this approach, it is not the intent of this Article to wade into the debate about whether consequentialist arguments are appropriate when it comes to constitutional decisionmaking. See Steven D. Smith, The Pursuit of Pragmatism, 100 YALE L.J. 409, 411 (1990) (examining "two common understandings of legal pragmatism: pragmatism as forward-looking instrumentalism, and pragmatism as a hostility to abstract theory, formalism, and foundationalism"); see also Peter Brandon Bayer, Sacrifice and Sacred Honor: Why the Constitution is a "Suicide Pact," 20 WM. \& MARY BILL RTS. J. 287, 293 (2011) ("[T]he fundamental dispute of whether principles must dominate, or are dominated by, consequences continues to fume among professed deontologists, avowed consequentialists and those who espouse hybrid approaches."). Instead, it is my hope that even those who have been most critical of such an approach would nonetheless agree that it has merit in this context. See, e.g., Ronald Dworkin, Reply, 29 ARIZ. ST. L.J. 432, 433 (1997) ("Of course, in some circumstances, pointing out that a doctrine will have surprising consequences - that a welfare program designed to help a particular group will actually harm that group, for example - is obviously immensely helpful.”). 
an enterprise that, despite appearing more personally beneficial, is ultimately harmful to the larger society. That enterprise would be permanent separation - and perhaps even subsequent remarriage to a new spouse-without legally terminating the first marriage. In such situations, great harm could quite easily accrue to the first spouse, who never received a day in court to ensure fair treatment and equitable division of assets. ${ }^{41}$ Likewise, a subsequent spouse would be harmed by learning that the marriage was not, in fact, monogamous, and consequentially, that as merely one of several spouses, any property rights from the marriage are accordingly diluted. ${ }^{42}$ All of these harms would, in turn, significantly undermine the states' interest in protecting the "communal health, comfort, and welfare" 43 of their citizens"collective interests that no individual, acting alone, has the capacity to vindicate." 44 Finally, any attempts by the state to ameliorate those harms by crafting additional, more stringent requirements for plural marriage-such as requiring the consent of all parties-would ultimately fail given the very real concerns with duress that surround polygamous marriage. ${ }^{45}$

To develop this argument, Part I of this Article explores the evolution of the practice of polygamy and the current role that it plays in the United States. Part II then looks at the institution of marriage, focusing on its evolution from an institution within the states' complete authority to a fundamental right subject to significant constitutional protections. Shifting from marriage to divorce, Part III explores the protections that legal divorce affords spouses, both current and subsequent, as well as the incentives built into family law to encourage formal divorce among separating couples. Finally, Part IV argues that a ruling requiring the states to permit polygamy would eviscerate not only the incentives favoring divorce, but the corresponding protections the practice affords, resulting in substantial harm to both the individual and the state-harms that cannot be overcome by attempting to limit

41. See infra Part IV.A.1.

42. See infra Part IV.A.2.

43. Lawrence O. Gostin \& Lindsay F. Wiley, Public Health Law: Power, Duty, RESTRAINT 91 (2016).

44. Id.; see also Michael L. Rich, Brass Rings and Red-Headed Stepchildren: Protecting Active Criminal Informants, 61 AM. U. L. REV. 1433, 1446 (2012) ("The protection of the vulnerable is one of the principal duties of society and a foundational goal of the legal system.").

45. See infra Part IV.B; see also Jacob Richards, Note, Autonomy, Imperfect Consent, and Polygamist Sex Rights Claims, 98 CALIF. L. REV. 197, 201 (2010) ("[S]ubcultural and religious constraints make the consent of women to polygamous relationships questionable or invalid."). 
the availability of polygamy to those who affirmatively consent to entering into such a marriage.

\section{Polygamy: PRACTICE AND PREVAlEnCE Within the United STATES}

At one time, polygamy was permitted in most parts of the world. Today, however, polygamy is largely relegated to countries in Africa, the Middle East, and Asia. ${ }^{46}$ Within the United States, the practice has always been - to put it mildly-disfavored. In fact, since America's earliest days, the practice has been strictly illegal. "At the time of the founding of the nation, England and Wales prohibited polygamy, and each of the original thirteen states passed antipolygamy statutes. Criminalization was the norm." $" 47$

It would be a mistake, however, to trace current prohibitions and public attitudes about polygamy solely to those early laws. ${ }^{48}$ Instead, current restrictions exist largely as a reaction to the emergence in the 1800s of the Church of Jesus Christ of Latter-day Saints (LDS Church):

Polygamy in the United States is often considered to be "human-

46. Martha Bailey \& Amy J. Kaufman, Polygamy in the Monogamous World: Multicultural CHALlENGES FOR WESTERn LAW AND POLICY 7 (2010); see also Reynolds v. United States, 98 U.S. 145, 164 (1878) ("Polygamy has always been odious among the northern and western nations of Europe, and, until the establishment of the Mormon Church, was almost exclusively a feature of the life of Asiatic and of African people.").

47. Shayna M. Sigman, Everything Lawyers Know About Polygamy Is Wrong, 16 CORNELL J.L. \& PUB. POL'Y 101, 108 (2006).

48. See id. ("The history of the criminalization of polygamy in the United States-especially the enforcement of any prohibitions on polygamous family structures-reveals a far more complex story than "once and always banned."'). In a case from 1890, the Supreme Court provided a glimpse into the early objections to the practice of plural marriage when Justice Field characterized such unions as follows: "They tend to destroy the purity of the marriage relation, to disturb the peace of families, to degrade woman, and to debase man. Few crimes are more pernicious to the best interests of society, and receive more general or more deserved punishment." Davis v. Beason, 133 U.S. 333, 341 (1890). Justice Field also stated that "[b]igamy and polygamy are crimes by the laws of all civilized and Christian countries," indicating that both religious and racial discrimination likely motivated early prohibitions. Id. In terms of contemporary objections to the practice of polygamy, however, Professor Maura Irene Strassberg identifies two primary arguments: first, "protecting women and children from crimes such as 'incest, sexual assault, statutory rape, and failure to pay child support"; and second, "the state's 'interest in preventing [both] the misuse of government benefits associated with marital status' as well [as] the crime of 'failure to pay child support."' Maura Irene Stassberg, Can We Still Criminalize Polygamy: Strict Scrutiny of Polygamy Laws Under State Religious Freedom Restoration Acts After Hobby Lobby, 2016 U. ILL. L. REV. 1605, 1617, 1622 (2016) (first alteration in original) (quoting State v. Holm, 137 P.3d 726, 744 (Utah 2006); then quoting State v. Green, 99 P.3d 820, 830 (Utah 2004)). 
made" in the sense that it can be readily tracked to a specific individual . . . . By all accounts, on July 12, 1843, Joseph Smith, Jr., informed the members of the church that he had a revelation that the faith should adopt the practice of plural marriage. . . . More than 30 years after Smith's revelation, the Mormon scriptures finally included written documentation of the event. ${ }^{49}$

Joseph Smith, himself, would ultimately wed at least thirty-three women, ${ }^{50}$ and the LDS Church would come to classify polygamy as not only "a necessary step to reach the highest levels of heaven, but as a prerequisite for the second coming of Jesus Christ on Earth, and as a requirement for advancement within the Church." 51

The reaction of the federal government was both swift and severe. Characterized-along with slavery-as one of the "twin relics of barbarism," 52 polygamy quickly became the subject of two congressional acts designed to eradicate the practice. The first was the 1862 Morrill Act, which criminalized bigamy by providing that no married individual could "marry any other person, whether married or single, in a Territory of the United States." 53 Those who violated the Act could be fined, imprisoned or both. ${ }^{54}$ The law, clearly aimed at the LDS Church in the then-territory of Utah, ultimately did very little to achieve its goal of punishing polygamists and thus discouraging the practice. Under the territory's existing laws, any conviction would have had to be handed down by a jury, which, as a practical matter, would have been comprised predominantly of other, sympathetic Mormons. ${ }^{55}$

49. Marilyn J. Coleman \& Lawrence H. Ganong, The Social History of the AMERICAN FAMILY: AN ENCYClOPEDIA 1049 (2014); see CHURCH OF JESUS CHRIST OF LATTER-DAY SAINTS, DOCTRINE AND COVENANTS, http://scriptures.lds.org/dc/132/61-62 [https://perma.cc/5YZP-FLFX] ("[I]f any man espouse a virgin, and desire to espouse another, and the first give her consent, and if he espouse the second, and they are virgins, and have vowed to no other man, then ... he cannot commit adultery with that that belongeth unto him and to no one else.").

50. See Todd Compton, In SACRed Loneliness: The Plural Wives Of JosePH SMith 10 (1997) (identifying thirty-three wives). But see GEORGE D. SMITH, NAUVOO POLYGAMY 54 (2008) (putting the number at thirty-seven wives).

51. BAILEY \& KAUFMAN, supra note 46 , at 84 .

52. Martha M. Ertman, Race Treason: The Untold Story of America's Ban on Polygamy, 19 COLUM. J. GENDER \& L. 287, 307 (2010).

53. The Morrill Act of 1862, ch. 126, § 1, 12 Stat. 501 (1862).

54. Mary K. Campbell, Mr. Peay's Horses: The Federal Response to Mormon Polygamy, 1854-1887, 13 YALE J.L. \& FEMINISM 29, 38 (2001) ("Multiple marriages subjected the offender to a five hundred dollar fine, five years in prison, or both.").

55. Jonathan Bressler, Reconstruction and the Transformation of Jury Nullification, $78 \mathrm{U}$. CHI. L. REV. 1133, 1192-93 (2011) ("Mormons still exercised absolute control over Utah's legal 
In 1874, then, Congress passed the Poland Act, at the heart of which were provisions giving federal courts jurisdiction over cases involving criminal bigamy, thus essentially "transferring plural marriage cases from the Mormon-controlled probate courts to the non-Mormon federal system." 56

Believing the criminalization of polygamy unconstitutional, the LDS Church challenged Congress's attempts to target polygamy. After George Reynolds was charged with bigamy under the Morrill Act, ${ }^{57}$ he challenged the conviction all the way to the U.S. Supreme Court, arguing that the conviction violated his First Amendment right to religious liberty. The Court, in Reynolds v. United States, ${ }^{58}$ unanimously rejected this argument. As an initial matter, the Court noted that First Amendment protections encompass religious beliefs but not religious actions "in violation of social duties or subversive of good order." 59 Turning then to the "action" of polygamy, the Court ruled that the Founders did not intend the First Amendment to cover such activity:

Polygamy has always been odious among the northern and western nations of Europe, and, until the establishment of the Mormon Church, was almost exclusively a feature of the life of Asiatic and of African people. At common law, the second marriage was always void, and from the earliest history of England polygamy has been treated as an offence against society. ... [Furthermore,] we think it may safely be said there never has been a time in any State of the Union when polygamy has not been an offence against society, cognizable by the civil courts and punishable with more or less severity. In the face of all this evidence, it is impossible to believe that the constitutional guaranty of religious freedom was intended to prohibit legislation in respect to this most important feature of social

apparatus. The territorial legislature ... grant[ed] extensive criminal jurisdiction to the local probate courts, but it also empowered local Mormon marshals, rather than federal officials, to summon jurors even for the federal courts.").

56. Campbell, supra note 54, at 39 .

57. George Reynolds, who was secretary to the president of the LDS Church, agreed to participate in this test case. See SARAH Barringer Gordon, THE MORMOn Question: POLYGAMY AND CONSTITUTIONAL CONFLICT IN NINETEENTH-CENTURY AMERICA 114 (2003).

58. Reynolds v. United States, 98 U.S. 145 (1878).

59. Id. at 164. Subsequently, in Davis v. Beason, 133 U.S. 333 (1890), the Court questioned the Mormons' right to even believe. There, the Court upheld a statute that required voters in the then-territory of Idaho to sign an oath swearing that they were not "a member of any order, organization, or association which teaches, advises, counsels, or encourages its members, devotees, or any other person, to commit the crime of bigamy or polygamy." Id. at 347. 
life. ${ }^{60}$

The Court concluded that Reynolds' argument - which would allow people to flout the law if their religion mandated it - would "make the professed doctrines of religious belief superior to the law of the land, and in effect [] permit every citizen to become a law unto himself." 61 According to Justice Vinson, writing for the Court, "Government could exist only in name under such circumstances." 62

Acceptance of the Court's ruling that religious liberty does not shield members of the LDS Church from criminal prosecution, coupled with additional congressional acts that increased the penalties and grounds for prosecution relating to polygamy, ${ }^{63}$ led to waning support among Mormons. ${ }^{64}$ Soon thereafter, even the Church itself started distancing itself from the practice of plural marriage. In 1890, the president of the LDS Church officially declared that the Church "did not teach polygamy or plural unions and did not permit any Church member to enter into such a union." ${ }^{65}$ In light of this developmentand the fact that Utah Territory had proposed a state constitution that expressly prohibited polygamy - Utah was finally granted statehood in 1896.66

Although the LDS Church officially disavowed the practice over 125 years ago, polygamy nonetheless continues to exist within smaller, often isolated communities that identify themselves as fundamentalist

60. Id. at 164-65. As this quote suggests, the United States' reaction to polygamy was motivated, at least in part, by racism, xenophobia, and religious intolerance. See supra note 48.

61. Reynolds, 98 U.S. at 167.

62. Id.

63. See generally Campbell, supra note 54, at 40-51 (discussing the Edmunds Act, ch. 47, $\S \S 1,3$, 22 Stat. 30, 30-31 (1882) (codified at 48 U.S.C. $\$ 1461$ ) (repealed 1983) and the EdmundsTucker Act, ch. 397, §§ 17-18, 24 Stat. 635 (1887) (codified at 28 U.S.C. $\S \$ 633,660$ ) (repealed 1978)).

64. See R. Michael Otto, "Wait 'Til Your Mothers Get Home": Assessing the Rights of Polygamists as Custodial and Adoptive Parents, 1991 UTAH L. REV. 881, 894 ("By 1890, the weight of this authority had become too much for even the resilient Mormons to withstand. The imprisonment or forced exile of many of the Church's leading authorities had all but decimated the Church.").

65. BAILEY \& KAUfMAN, supra note 46, at 93; see also JOHN WITTE, JR., THE WESTERN CASE OF MONOGAMY Over POlygamy 436-37 (2015) ("Although polygamous ideas and practices lingered for a generation, giving rise to internal ecclesiastical disputes and cases, by 1906, the Mormon Church had made the preaching and practice of polygamy a ground for excommunication.").

66. See Sandra Day O'Connor, The History of the Women's Suffrage Movement, 49 VAND. L. REV. 657, 663 (1996). 
Mormon ${ }^{67}$ Statistics relating to just how many of these communities remain are difficult to come by; nonetheless, it has been estimated that there are between 37,000 and 100,000 such polygamists living in the United States and Canada. ${ }^{68}$ The Fundamentalist Church of Jesus Christ of Latter-day Saints (FLDS)-one of the larger organized communities practicing polygamy - has been estimated to have about 8,000 members alone. ${ }^{69}$ Although plural marriages within these communities remain both invalid and illegal, prosecutions for bigamy are exceedingly rare. ${ }^{70}$

In addition to Mormon fundamentalists, the United States also encounters incidences of polygamy within certain immigrant communities. ${ }^{71}$ Not all countries ban polygamy, so "[e]ach year, hundreds of thousands of immigrants enter the United States from countries in which polygamy is legal."72 Given the concern that plural marriage might immigrate into the United States along with those who practice it, Congress has repeatedly attempted to bar polygamists from entering the United States:

67. D. Michael Quinn, Plural Marriage and Mormon Fundamentalism, in FUnDAMENTALISMS AND SocieTY 240, 276 (Martin E. Marty \& R. Scott Appleby eds., 1993) ("There are ten times more polygamists now in the United States than in 1862, the year of the first federal law against polygamy.").

68. BAILEY \& KAUFMAN, supra note 46 , at 95

69. Id. ("Members of the FLDS believe they are the true Latter-day Saints, as they are living Joseph Smith's revelation that men must have at least three wives to enter the highest realm of heaven.").

70. See supra note 19 and accompanying text. Nonetheless, many in these communities have been subject to police investigation and criminal prosecution for other crimes, typically those relating to sexual abuse of minors. See generally Martin Guggenheim, Texas Polygamy and Child Welfare, 46 Hous. L. REV. 759 (2009) (discussing the two major efforts police undertook to break up polygamous communities); Jonathan Turley, The Loadstone Rock: The Role of Harm in the Criminalization of Plural Unions, 64 EMORY L.J. 1905 (2015) (discussing a Canadian case alleging sexual abuse against polygamists); Jessica Dixon Weaver, The Texas Mis-Step: Why the Largest Child Removal in Modern U.S. History Failed, 16 WM. \& MARY J. WOMEN \& L. 449 (2010) (discussing the breakup of the Yearning for Zion Ranch community of polygamists where a minor alleged that her spiritual husband sexually abused her); Amy Fry, Comment, Polygamy in America: How the Varying Legal Standards Fail To Protect Mothers and Children from Its Abuses, 54 ST. LoUIS U. L.J. 967 (2010) (recounting situations where minors were the subjects of crimes in polygamous communities).

71. See Jamie M. Gher, Polygamy and Same-Sex Marriage-Allies or Adversaries Within the Same-Sex Marriage Movement, 14 WM. \& MARY J. WOMEN \& L. 559, 577 (2008) ("In addition to fundamentalist Mormons, it is suspected that there are a significant number of immigrant families engaging in polygamy in the United States.").

72. Smearman, supra note 39, at 385 ("According to the Department of Homeland Security (DHS), in 2007 alone, close to half a million immigrants obtained lawful permanent resident status from countries in which polygamy is practiced in Africa, Asia, and the Middle East.”). 
[P]olygamy has been a bar to admission to the United States since the Immigration Act of 1891. Polygamy as a ground of inadmissibility casts a long shadow throughout the Immigration and Nationality Act of 1952 (INA), the foundation of present immigration law. Currently codified at INA $\S 212(\mathrm{a})(10)(\mathrm{A})$, the polygamy ground of inadmissibility (the polygamy bar) is incorporated into numerous provisions of the INA, ranging from adjustment of status (the process for obtaining a green card) to deportation and naturalization. The INA does not recognize a polygamous marriage as a valid marriage for immigration purposes, includes polygamy as a statutory bar to a finding of good moral character, and lists bigamy, the criminal law under which polygamy is typically prosecuted, [as] a crime of moral turpitude. ${ }^{73}$

But such attempts can hardly be expected to weed out every polygamist who attempts to enter the country. In addition, these prohibitions only apply to practicing polygamists and not to individuals who, though not currently practicing, emigrate from cultures where plural marriage is encouraged and perhaps expected. It should therefore come as little surprise to discover that polygamy exists in a variety of immigrant communities in the United States, ranging "from groups of African immigrants in New York City to Hmong immigrants from Vietnam living in Minneapolis." 74

In sum, plural marriage has a long history of being subject to criminal prohibition and widespread social condemnation in the United States. Nonetheless, the practice survives in communities throughout the country to this day. Many believe the number of people living in polygamous households may continue to grow. ${ }^{75}$ As a result, the Court's recent decision legalizing same-sex marriage-which, like polygamy, was also once subject to legal and social disdain-has led

73. Id. at $383-84$

74. Id. at 387; see also BAILEY \& KAUFMAN, supra note 46, at 96 (referencing a radio show on NPR that "profiled a family in Philadelphia where the husband, already married to one woman, had gone through a Muslim religious marriage ceremony with another woman").

75. See Janet Bennion, Polygamy in Primetime: Media, Gender, and Politics in MORMON FUNDAMENTALISM 263 (2012) (discussing the "growing number of Muslims who believe they are allowed four wives according to the Quran"); Cyra Akila Choudhury, Between Tradition and Progress: A Comparative Perspective on Polygamy in the United States and India, 83 U. COLO. L. REV. 963, 967 (2012) ("[T]he practice flourishes in some communities even if driven into the closet by the law, and its incidence in the United States might be increasing."); Pauline Bartolone, Opinion, For These Muslims, Polygamy Is an Option, SAN FRANCISCO CHRONICLE (Aug. 5, 2007, 4:00 AM), http://www.sfgate.com/opinion/article/For-these-Muslimspolygamy-is-an-option-2549200.php [https://perma.cc/96ER-YTL2] (describing increased practice of polygamy among African-American Muslims). 
people to question whether plural marriage could soon follow suit. In considering that ultimate question, however, it would be short sighted to focus exclusively on the impact legalization would have on the polygamous communities discussed here; instead, one must also take into account the effect legalization might have on sequential bigamists. And, as discussed below in Parts III and IV, that impact would be significant.

\section{THE FUNDAMENTAL RIGHT TO MARRY: A BRIEF OVERVIEW}

Although the law of domestic relations is generally seen as the exclusive province of the states, the Supreme Court has, over time, increasingly limited the states' ability to regulate marriage. This evolution has taken place relatively recently: in 1888, the Supreme Court in Maynard v. Hill ${ }^{76}$ recognized, albeit in dicta, that "[m]arriage . . . has always been subject to the control of the legislature."77 If that standard were still the case today, polygamy would likely have no chance of resurrection. After all, no state permits plural marriage. ${ }^{78}$ Every state has explicitly made the practice illegal. For political reasons, it is unlikely that a state would legislatively reverse course. Since Maynard was written, however, the Supreme Court has recognized that, under the Due Process Clause of the Fourteenth Amendment, there are notable limits to a state's ability to regulate marriage. ${ }^{79}$ Specifically, the Court has declared that, under the substantive component of the Due Process Clause of the Fourteenth Amendment, the right to marry is a fundamental right. ${ }^{80}$ Accordingly, any law depriving a citizen of that right is subject to strict scrutiny, requiring that law to be a necessary response to a compelling government objective ${ }^{81}-\mathrm{a}$ level of scrutiny routinely described as "strict in theory, fatal in fact." 82 In light of these constitutional

76. Maynard v. Hill, 125 U.S. 190 (1887).

77. Id. at 205 (emphasis added).

78. See supra notes 47-48 and accompanying text; see also Anne Laquer Estin, Underground Family Law, in MARriage AND Divorce in a Multicultural ConteXt: Multi-Tiered MARRIAGE AND THE BOUNDARIES OF CIVIL LAW AND RELIGION 92, 115 (Joel A. Nichols ed., 2011) ("Official laws in the United States prohibit and sanction polygamy at every level, from national immigration statutes to local criminal law.").

79. See United States v. Windsor, 133 S. Ct. 2675, 2692 (2013) (recognizing that the states' interest in regulating marriage is limited by constitutional guarantees).

80. See infra notes $85-98$ and accompanying text.

81. Lynn A. Stout, Strict Scrutiny and Social Choice: An Economic Inquiry into Fundamental Rights and Suspect Classifications, 80 GEO. L.J. 1787, 1787 (1992).

82. Wittmer v. Peters, 87 F.3d 916, 918 (7th Cir. 1996) (noting how "subject to strict scrutiny" 
limitations, it might be that - and indeed some have argued that ${ }^{83}-$ states cannot prohibit polygamous marriages. ${ }^{84}$

Although the Court noted the importance of the right to marry as early as $1942,{ }^{85}$ it was not until the Court's 1967 decision in Loving $v$. Virginia $^{86}$ that the Court would explicitly characterize the right as fundamental. ${ }^{87}$ In Loving, the Court was confronted with Virginia's antimiscegenation statute, which made it "unlawful for any white person in [Virginia] to marry [anyone except another] white person." 88 Richard Loving and Mildred Jeter, an interracial couple, had violated the statute when they married in D.C. and subsequently moved to Virginia. ${ }^{89}$ After being arrested, the two pled guilty and received a oneyear jail sentence. ${ }^{90}$ The judge suspended their sentence but only on the condition that they leave the state for twenty-five years. ${ }^{91}$ In ruling as he did, the judge infamously reasoned, "Almighty God created the races white, black, yellow, malay and red, and he placed them on separate continents .... The fact that he separated the races shows that he did not intend for the races to mix." 92

On appeal, the Court first noted that "[w]hile the state court is no

has often been thought of as a "euphemism for 'absolutely forbidden"”).

83. See, e.g., Ronald C. Den Otter, Three May Not Be a Crowd: The Case for a Constitutional Right to Plural Marriage, 64 EMORY L.J. 1977, 2044 (2015) (taking the position that "as the state remains in the marriage business, it must legally recognize any intimate relationship that competent, consenting adults want to form, regardless of its number, gender composition, or interpersonal dynamics, provided that the behaviors do not violate other valid laws"); Jack B. Harrison, On Marriage and Polygamy, 42 OHIO N.U. L. REV. 89, 146 (2015) ("Has the Supreme Court, both in its cases recognizing the fundamental right to marry and in its developing gay rights jurisprudence ... created a pathway for a future recognition of polygamous marriage? This Article argues that is indeed what the Court has done.").

84. See Casey E. Faucon, Polygamy After Windsor: What's Religion Got to Do with It?, 9 HARV. L. \& POL'Y REV. 471, 528 (2015) (“[H]igher courts and legislatures may very well have to square the issue of polygamy with modern conceptions of marriage and liberty sooner than anticipated.").

85. Skinner v. Oklahoma ex rel. Williamson, 316 U.S. 535, 541 (1942) (stating that "[m]arriage and procreation are fundamental to the very existence and survival of the race").

86. Loving v. Virginia, 388 U.S. 1 (1967).

87. ROGER J. R. LEVESQUE, CHILD MALTREATMENT AND THE LAW: RETURNING TO FIRST PRINCIPLES 46 (2009) (noting that, prior to Loving, "the Court had yet to rule that marriage itself was a fundamental right deserving robust constitutional protection").

88. Loving, 388 U.S. at 5 n.4.

89. Id. at 2 .

90. Id. at 3

91. Id. For a more comprehensive discussion of the Lovings and their journey to the Supreme Court, see generally Robert A. Pratt, The Case of Mr. and Mrs. Loving: Reflections on the Fortieth Anniversary of Loving v. Virginia, in FAMILY LAW STORIES 7 (Carol Sanger ed., 2008).

92. Loving, 388 U.S. at 3 (quoting the Virginia trial judge). 
[Vol. 67:79

doubt correct in asserting that marriage is a social relation subject to the State's police power, the State [correctly] does not contend ... that its powers to regulate marriage are unlimited notwithstanding the commands of the Fourteenth Amendment." ${ }^{93}$ In other words, what the Court had previously stated in Maynard about the states' broad authority to regulate marriage was actually subject to constitutional regulations. The Court then turned to two such constitutional limitations to strike down the Virginia law. First, the Court held that the statute violated the equal protection clause of the Fourteenth Amendment. ${ }^{94}$ As the Court noted, the statute "prohibits only interracial marriages involving white persons," and was thus designed to promote white supremacy. ${ }^{95}$

Although the Court's opinion could have stopped there, the Court went on to hold that the statute also ran afoul of the Due Process Clause of the Fourteenth Amendment. The Court noted that "[t]he freedom to marry has long been recognized as one of the vital personal rights essential to the orderly pursuit of happiness by free men." 96 In light of that recognition, the Court spent little time finding that the Virginia law violated substantive due process:

To deny this fundamental freedom on so unsupportable a basis as the racial classifications embodied in these statutes, classifications so directly subversive of the principle of equality at the heart of the Fourteenth Amendment, is surely to deprive all the State's citizens of liberty without due process of law. The Fourteenth Amendment requires that the freedom of choice to marry not be restricted by invidious racial discriminations. Under our Constitution, the freedom to marry or not marry, a person of another race resides with the individual and cannot be infringed by the State. ${ }^{97}$

With that, the Court ruled that the Virginia law was unconstitutional. In the process, the Court issued what is today regarded as one of its most landmark decisions relating to the law of the family. ${ }^{98}$

\footnotetext{
93. Id. at 7 (emphasis added) (citing Maynard v. Hill, 125 U.S. 190 (1888)).

94. Id. at 11. In reaching this conclusion, the Court noted the state's proffered justifications "'to preserve the racial integrity of its citizens,' and to prevent 'the corruption of blood,' 'a mongrel breed of citizens,' and 'the obliteration of racial pride ...."' Id. at 7 (quoting Naim v. Naim, 87 S.E.2d 749, 756 (Va. 1955)).

95. Id. at 11 .

96. Id. at 12 .

97. Id.

98. See Robert A. Destro, Law and the Politics of Marriage: Loving v. Virginia After 30 Years: Introduction, 47 CATH. U. L. REV. 1207, 1209 (1998) ("Loving v. Virginia is, by any
} 
Since Loving, the Court has decided three other key cases in which it has reaffirmed its understanding of marriage as a fundamental right. ${ }^{99}$ A little over ten years after Loving, the Court in Zablocki v. Redhail ${ }^{100}$ was confronted with a Wisconsin statute that prohibited a noncustodial parent who had to pay child support from obtaining a marriage license without court approval. ${ }^{101}$ The statute further prohibited a court from granting such permission unless the support obligation had been met and the children in question "[were] not then and [were] not likely thereafter to become public charges." 102 Roger Redhail brought a constitutional challenge to the law after his request for a marriage license was denied. ${ }^{103}$ The Court ruled that the Wisconsin law unconstitutionally violated his fundamental right to marry. ${ }^{104}$ The Court noted that, under the statute in question, individuals like Redhail, who were incapable of paying their child support obligation, would be "absolutely prevented from getting married." 105 For others, who were "able in theory to satisfy the statute's requirements," they could nonetheless "be sufficiently burdened by having to do so that they will in effect be coerced into forgoing their right to marry."106

Given the degree to which the Wisconsin statute interfered with the fundamental right to marry, the Court applied strict scrutiny, meaning that the law in question could only be upheld if "supported by sufficiently important state interests" and "closely tailored to effectuate only those interests." 107 Despite the state's attempts to justify the law, the Court ruled that, even if those interests were "legitimate and substantial," the statute could not be upheld because it was simply too broad. ${ }^{108}$ Thus, "the means selected by the State for

\footnotetext{
definition, a landmark case."); Jill Elaine Hasday, The Canon of Family Law, 57 STAN. L. REV. 825, 854-55 (2004) ("Legal authorities and legal scholars consistently identify Loving as one of the most crucial decisions in family law, illuminating family law's nature and core values.").

99. See Obergefell v. Hodges, 135 S. Ct. 2584 (2015); Turner v. Safley, 482 U.S. 78 (1987); Zablocki v. Redhail, 434 U.S. 374 (1978).

100. Zablocki v. Redhail, 434 U.S. 374 (1978).

101. Id. at 375 .

102. Id. (quoting WIS. STAT. $\$ 245.10$ (repealed 1977)).

103. Id. at 376.

104. Id. at 383 .

105. Id. at 387. Redhail fathered a child while he was in high school and, at the time Redhail sought to obtain a marriage license, he had not only failed to satisfy his support obligations to the child, but "the child had been a public charge since her birth, receiving benefits under the Aid to Families with Dependent Children program." Id. at 377-78.

106. Id. at 377 .

107. Id. at 388 .

108. Id.
} 
achieving these interests unnecessarily impinge on the right to marry."109 In an attempt to clarify what forms of state regulation pertaining to marriage were permissible, the Court was clear that it did not "mean to suggest that every state regulation which relates in any way to the incidents of or prerequisites for marriage must be subjected to rigorous scrutiny. To the contrary, reasonable regulations that do not significantly interfere with decisions to enter into the marital relationship may legitimately be imposed." 110

Almost ten years later, in Turner v. Safley, ${ }^{111}$ the Court would once again be called upon to apply the fundamental right to marriage. In that case, the law at issue arose from regulations promulgated by the Missouri Division of Corrections. ${ }^{112}$ The regulation in question, motivated by security concerns ${ }^{113}$ permitted "an inmate to marry only with the permission of the superintendent of the prison, and provide[d] that such approval should be given only "when there are compelling reasons to do so." "114 The Court ruled that the regulation in question was far too overinclusive and, thus, unconstitutional. ${ }^{115}$ Specifically, the Court stated that " $[\mathrm{t}]$ here are obvious, easy alternatives to the Missouri regulation that accommodate the right to marry while imposing a de minimis burden on the pursuit of security objectives." 116 In sum, the Court concluded that, although "Missouri prison officials may regulate the time and circumstances under which the marriage ceremony itself takes place .... [But] the almost complete ban on the decision to marry

109. Id. The interests put forward by the state were twofold. First, "the permission-to-marry proceeding furnishes an opportunity to counsel the applicant as to the necessity of fulfilling his prior support obligations...." Id. Second, the state expressed interests in encouraging noncustodial parents to meet and maintain their support obligations, and in protecting "the ability of marriage applicants to meet support obligations to prior children by preventing the applicants from incurring new support obligations" that might arise from a subsequent marriage. Id. at 390.

110. Id. at 386.

111. Turner v. Safley, 482 U.S. 78 (1987).

112. Id. at 81 .

113. Id. at 97 . The justifications advanced by Missouri included security concerns relating to the fear "that 'love triangles' might lead to violent confrontations between inmates" and rehabilitation concerns relating to the need for female inmates to focus on developing selfreliance. $I d$. To the latter point, the state argued that the "female prisoners often were subject to abuse at home or were overly dependent on male figures, and that this dependence or abuse was connected to the crimes they had committed." Id.

114. Id. at 82. The Court explained that "[t]he term 'compelling' is not defined, but prison officials testified at trial that generally only a pregnancy or the birth of an illegitimate child would be considered a compelling reason." $I d$.

115. Id. at 97-98.

116. Id. at 98 (citing 28 C.F.R. $§ 551.10$ (1986) (allowing inmates in federal prison to marry unless warden finds that the marriage would threaten security, order, or public safety)). 
is not reasonably related to legitimate penological objectives."117

Whereas Loving, Turner, and Zablocki all involved marriage restrictions deemed unconstitutional, lower courts have upheld a variety of other state restrictions on marriage. These restrictions include age requirements, ${ }^{118}$ prohibitions against incestuous marriage, ${ }^{119}$ and statutes requiring blood tests as a condition of marriage. ${ }^{120}$ In such instances, the laws at issue were seen merely as "reasonable regulations that do not significantly interfere with decisions to enter into the marital relationship." ${ }^{21}$ As LGBT advocates began advocating for same-sex marriage, however, states began to supplement these restrictions by adding gender requirements to their marriage laws. ${ }^{122}$ The question became whether such restrictions were within the province of the state or if, like the restrictions at issue in Turner, Zablocki, and Loving, these statutes were instead unconstitutional.

In 2015, that question was answered by the Court's historic ruling in Obergefell v. Hodges. ${ }^{123}$ In that case, the Court was called upon to decide whether a state could constitutionally deny same-sex couples the right to marry. The Court began by reaffirming its prior holdings that "the right to marry is protected by the Constitution." 224 The Court, however, could not rely exclusively on those prior holdings, given that each had clearly "presumed a relationship involving opposite-sex

117. Id. at 99 .

118. See, e.g., Moe v. Dinkins, 533 F. Supp. 623, 631 (S.D.N.Y. 1981) (holding that parental consent requirement for marriages by minors "does not offend the constitutional rights of minors but represents a constitutionally valid exercise of state power").

119. See, e.g., Singh v. Singh, 569 A.2d 1112, 1121 (Conn. 1990) (upholding state statute that voids incestuous marriage); State v. Sharon H., 429 A.2d 1321, 1330 (Del. 1981) (allowing an incest prosecution to proceed against a half brother and half sister who wed).

120. See, e.g., Peterson v. Widule, 147 N.W. 966, 971 (Wis. 1914) (upholding state law requiring a blood test as a condition precedent to receiving a marriage license).

121. Zablocki v. Redhail, 434 U.S. 374, 386 (1978). In fact, Justice Stewart, in his concurrence in Zablocki, opined that:

[s]urely, for example, a State may legitimately say that no one can marry his or her sibling, that no one can marry who is not at least 14 years old, that no one can marry without first passing an examination for venereal disease, or that no one can marry who

has a living husband or wife.

Id. at 392 (Stewart, J., concurring).

122. See Meredith Johnson Harbach, Is the Family a Federal Question?, 66 WASH. \& LEE L. REV. 131, 192 (2009) (noting that, in 2009, "[f]orty-five states prohibit[ed] same-sex marriage by statute, constitutional amendment, or both").

123. Obergefell v. Hodges, 135 S. Ct. 2584 (2015).

124. Id. at 2598 
partners." 125 Nonetheless, Justice Kennedy's opinion stated that a closer analysis of these previous cases "compels the conclusion that same-sex couples may exercise the right to marry." 126 Specifically, the Court identified four essential "principles and traditions" related to marriage that justify its classification as a fundamental rightprinciples and traditions that, according to the Court, apply with equal force to same-sex couples. ${ }^{127}$

First, the Court declared that "the right to personal choice regarding marriage is inherent in the concept of individual autonomy." 128 Citing Loving, the Court recognized that "[t]here is dignity in the bond between two men or two women who seek to marry and in their autonomy to make such profound choices." ${ }^{29}$ Second, the Court cited the understanding that marriage "supports a two-person union unlike any other in its importance to the committed individuals." 130 The Court explained that "[m]arriage responds to the universal fear that a lonely person might call out only to find no one there. It offers the hope of companionship and understanding and assurance that while both still live there will be someone to care for the other." 131 Third, the Court looked to other individual rights to reveal that marriage "safeguards children and families and thus draws meaning from related rights of childrearing, procreation, and education." ${ }^{132}$ Quoting Zablocki, where the Court held that "[ $[\mathrm{t}]$ he right to marry, establish a home and bring up children is a central part of the liberty protected by the Due Process Clause," ${ }^{133}$ the Court went on to explain that "[b]y giving recognition and legal structure to their parents' relationship, marriage allows children 'to understand the integrity and closeness of their own family and its concord with other

125. Id. The Court had, in fact, previously issued a decision relating to same-sex couples and their right to marry. In Baker v. Nelson, 409 U.S. 810 (1972) (mem.), the Court dismissed an appeal from a decision disallowing same-sex marriage for want of a federal question. $I d$. Obergefell overruled Baker. Obergefell, 135 S. Ct. at 2605.

126. Obergefell, $135 \mathrm{~S}$. Ct. at 2599

127. Id.

128. Id.

129. Id. The Court also explained that " $[\mathrm{t}] \mathrm{h}$. nature of marriage is that, through its enduring bond, two persons together can find other freedoms, such as expression, intimacy, and spirituality." Id.

130. Id.

131. Id. at 2600 .

132. Id.

133. Id. (internal quotations omitted) (quoting Zablocki v. Redhail, 434 U.S. 374, 384 (1978)). 
families in their community and in their daily lives." 134 Finally, the Court, relying on both precedent and tradition, held that "marriage is a keystone of our social order." 135 In other words, marriage is "the foundation of the family and of society, without which there would be neither civilization nor progress." ${ }^{\text {"136 }}$ In recognition of that importance, "just as a couple vows to support each other, so does society pledge to support the couple, offering symbolic recognition and material benefits to protect and nourish the union." 137

Having broken marriage down into those elements justifying its recognition as a fundamental right, the Court then turned its attention to same-sex unions, where it found no basis for holding that such relationships fall outside this right:

Same-sex couples, too, may aspire to the transcendent purposes of marriage and seek fulfillment in its highest meaning.

The limitation of marriage to opposite-sex couples may long have seemed natural and just, but its inconsistency with the central meaning of the fundamental right to marry is now manifest. With that knowledge must come the recognition that laws excluding same-sex couples from the marriage right impose stigma and injury of the kind prohibited by our basic charter. ${ }^{138}$

Accordingly, the Court held that the Due Process Clause of the Fourteenth Amendment prohibits states from denying same-sex couples the ability to marry on terms equal to those available to opposite-sex couples. ${ }^{139}$

In ruling as it did, the Court made sure to note that "these cases involve only the rights of two consenting adults whose marriages would pose no risk of harm to themselves or third parties." ${ }^{40}$ Thus, there is nothing in Obergefell that would explicitly require a state to recognize a plural marriage. Indeed, no court has applied Obergefell to reach such a conclusion. Some have nonetheless argued that the four principles of marriage outlined by Justice Kennedy could apply with equal force to

134. Id. (quoting United States v. Windsor, 133 S. Ct. 2675, 2694 (2013)). The Court continued: "Marriage also affords the permanency and stability important to children's best interests." Id.

135. Id. at 2601.

136. Id. (quoting Maynard v. Hill, 125 U.S. 190, 211 (1888)).

137. Id.

138. Id. at 2602

139. Id.

140. Id. at 2607 (emphasis added). 
polygamous marriages. ${ }^{141}$ After all, if the fact that marriage had historically been defined as male-female was no impediment to samesex marriage, why should the fact that it has been traditionally limited to two people prevent plural marriage from likewise falling within the fundamental right? Justice Roberts, in his dissent, suggested that such a ruling would actually be less remarkable than the one reached by the majority. "[F]rom the standpoint of history and tradition, a leap from opposite-sex marriage to same-sex marriage is much greater than one from a two-person union to plural unions, which have deep roots in some cultures around the world." ${ }^{142}$

\section{THE PROTECTIVE FUnCTION OF DIVORCE}

Legal divorce offers a variety of protections-protections that extend not only to the divorcing parties themselves, but also to those parties' subsequent spouses. As noted earlier and discussed more fully below, it is these protections that incentivize separating couples, who might find themselves in a prisoner's dilemma leading them to informal separation, to instead opt for formal divorce. Indeed, the states have a strong interest in promoting divorce-by protecting the parties to the marriage, divorce likewise advances the states' substantial interest in "the protection of an economically vulnerable spouse from great financial hardship at the end of marriage." ${ }^{143}$ Because divorce cannot exist without marriage, however, one must first understand the states' interest in marriage before one can fully understand the legal and societal value of divorce.

In short, marriage helps provide stability to adult relationships and also helps protect the welfare of the children resulting from those relationships. ${ }^{144}$ Marriage is thus an institution that American law strives to actively promote and encourage beyond its status as a

141. See supra note 83 and accompanying text

142. Obergefell, 135 S. Ct. at 2621 (Roberts, C.J., dissenting).

143. Gail Frommer Brod, Premarital Agreements and Gender Justice, 6 YALE J.L. \& FEMINISM 229, 233 (1994); see also Daniel B. Griffith, The Best Interests Standard: A Comparison of the State's Parens Patriae Authority and Judicial Oversight in Best Interests Determinations for Children and Incompetent Patients, 7 IssuEs L. \& MED. 283, 331 (1991) ("[T]he state's parens patriae power serves to protect all individuals of the state who cannot protect themselves.").

144. See Maxine Eichner, Marriage and the Elephant: The Liberal Democratic State's Regulation of Intimate Relationships Between Adults, 30 HARV. J.L. \& GENDER 25, 43 (2007) (noting the "important role the state can play in creating a stable environment that fosters the well-being of children by formalizing and privileging relationships such as marriage"). 
fundamental right. ${ }^{145}$ To make marriage a more attractive option, the law extends a number of advantages to married couples - what Justice Kennedy in Obergefell referred to as a "constellation of benefits" 146 :

These aspects of marital status include: taxation; inheritance and property rights; rules of intestate succession; spousal privilege in the law of evidence; hospital access; medical decisionmaking authority; adoption rights; the rights and benefits of survivors; birth and death certificates; professional ethics rules; campaign finance restrictions; workers' compensation benefits; health insurance; and child custody, support, and visitation rules. Valid marriage under state law is also a significant status for over a thousand provisions of federal law. ${ }^{147}$

According to Justice Kennedy, this panoply of rights partly contributes to the very classification of marriage as a fundamental right: "The States have contributed to the fundamental character of the marriage right by placing that institution at the center of so many facets of the legal and social order." 148

The flip side of marriage is, of course, divorce. Just as states aim to encourage marriage, it is the policy of every state to discourage divorce. ${ }^{149}$ It may seem somewhat ironic, then, that the states have-in the not too distant past-made divorce much easier to obtain. ${ }^{150}$ The most notable example of that shift would be the adoption of no-fault

145. See Huiet v. Atlanta Gas Light Co., 28 S.E.2d 83, 84 (Ga. Ct. App. 1943) ("Marriage is encouraged by the law, and every effort to restrain or discourage marriage by contract, condition, limitation, or otherwise, shall be invalid and void." (quoting GA. CODE ANN. § 53-107 (1933))).

146. Obergefell, 135 S. Ct. at 2601; see also Adam Chase, Tax Planning for Same-Sex Couples, 72 DENV. U. L. REV. 359, 359 (1995) (noting the "panoply of entitlements and privileges that come as part of the institution of marriage").

147. Obergefell, 135 S. Ct. at 2601 (citations omitted); see also Kara S. Suffredini \& Madeleine V. Findley, Speak Now: Progressive Considerations on the Advent of Civil Marriage for Same-Sex Couples, 45 B.C. L. REV. 595, 598 n.10 (2004) (detailing some of the " 1138 federal benefits, rights, and obligations" that flow from marriage).

148. Obergefell, 135 S. Ct. at 2601

149. See Tiffany N. Lee, Divorce and Dissolution, 2 GEO. J. GENDER \& L. 347, 360 (2001) (noting that many states, in response to the shift to no-fault divorce, have "taken measures to discourage divorce"); Peter Nash Swisher, Reassessing Fault Factors in No-Fault Divorce, 31 FAM. L.Q. 269, 290-91 (1997) ("Since marriage and the modern American family still serve a valuable social, legal, economic, and institutional function, the underlying public policy of most states continues to promote marriage and discourage divorce unless the parties comply with the required statutory guidelines for divorce."); Note, Interlocutory Decrees of Divorce, 56 CoLuM. L. REV. 228, 228 (1956) ("It is the policy of all states to encourage the continuance of the marital state and to discourage divorces.").

150. See JoAn Hoff, Law, Gender, \& InJustice: A Legal History of U.S. Women 291 (1994) (noting that, since 1969, all state reforms related to marriage dissolution "have generally made divorce easier to obtain"). 
divorce. ${ }^{151}$ Previously, married couples could not obtain a divorce unless one of the parties could prove one of several fault-based grounds, including adultery, desertion, and cruelty. ${ }^{152}$ But the shift away from requiring fault was necessary-somewhat ironically-to promote marriage. ${ }^{153}$ With the sexual revolution, the stigma that accompanied cohabitation without marriage was greatly eroded, so much so that couples faced an increasing temptation to elect this more informal living situation. ${ }^{154}$ After all, the more difficult it is to extricate oneself from marriage, the greater the temptation to simply cohabitate. ${ }^{155}$ Judge Richard A. Posner explains that " $[\mathrm{t}]$ he more costly a mistake is, the less likely it is to be committed; and a mistake in choosing a spouse is more costly in a system that forbids divorce (or makes it very difficult) than in one that permits it." 156 In other words, when obtaining divorce becomes too difficult, another example of a prisoner's dilemma arises, one that would encourage couples not to marry and instead elect a more informal living arrangement. To avoid that likelihood, the states made divorce easier to obtain, thus providing more incentive for couples to avoid such temptations and opt for a formal marriage. ${ }^{157}$

151. Rebecca E. Silberbogen, Does the Dissolution of Covenant Marriages Mirror Common Law England's Subordination of Women?, 5 WM. \& MARY J. WOMEN \& L. 207, 224 (1998) ("Since the introduction of no-fault divorce, divorces are easier to obtain ....").

152. See generally Adriaen M. Morse Jr., Fault: A Viable Means of Re-Injecting Responsibility in Marital Relations, 30 U. RICH. L. REV. 605 (1996) (arguing for "re-injecting some elements of fault into the process of marital dissolution").

153. Roderick Phillips, Putting Asunder: A History of Divorce in Western SOCIETY 571-72 (1988) (describing no-fault divorce as resulting from "wide-sweeping liberalization of attitudes toward many institutions and forms of behavior that was characteristic of the 1960s and 1970s").

154. See Maggie Gallagher \& Barbara Dafoe Whitehead, End No-Fault Divorce?, FIRST THINGS (Aug. 1997), https://www.firstthings.com/article/1997/08/end-no-fault-divorce\#print [https://perma.cc/8UHH-YQBL] ("The states adopted no-fault divorce laws in the 1970s in an effort to bring legal norms into closer conformity with the more permissive extralegal norms."). As Whitehead explains, "[t]he divorce revolution was a cultural rather than legal phenomenon. It grew out of a historic transformation in ideas and practices regarding sex, marriage, and parenthood." Id.

155. See Antony W. Dnes, Cohabitation and Marriage, in THE LAW AND ECOnOMics of MARRIAGE AND DIVORCE 118, 129 (Antony W. Dnes \& Robert Rowthorn eds., 2002) ("[T]he growth in cohabitation may be nothing more than a rational response to rather messy marital laws.").

156. Richard A. POSNER, ECONOMIC ANALYSIS OF LAW § 5.2, at 165 (9th ed. 2014).

157. See Gallagher \& Whitehead, supra note 154, at 28 ("For a generation so worried and confused, the impact of fault law is more likely to discourage marriage than encourage it."); see also Elizabeth S. Scott, Rational Decisionmaking about Marriage and Divorce, 76 VA. L. REV. 9 , 13 (1990) (noting how fault-based divorced imposed "costs on divorce"). 
Lowering the restrictions on divorce offers one additional benefit-it helps ensure that those desiring to end their relationship actually go through the formal process of obtaining a divorce, rather than simply dividing up the property themselves and going their separate ways. In this limited sense (that is, when the options are either desertion or divorce), the law does wish to encourage divorce. ${ }^{158}$ After all, doing so protects not only the parties themselves, but the parties' subsequent spouses, all of which helps safeguard the state's interest in protecting its citizens from economic and social harm.

\section{A. Protections for Former Spouses}

Marriage is often analogized to a business partnership and, correspondingly, divorce to a partnership dissolution proceeding. ${ }^{159}$ Such an analogy, however, is far from perfect given that there are crucial differences between business structures and marital unions. As Posner points out, the dissolution of a marriage is unlike that of a business partnership because "the division of the marital income may not be determined by the relative value of each spouse's contribution." 160 In a marriage, "each may derive utility from the consumption expenditures of the other."161 Accordingly, divorce proceedings contain a number of difficulties not present in proceedings to divide a partnership:

When a conventional partnership is dissolved, the assets of the partnership must be distributed among the partners, and it is the same with marriage. But determining the spouses' respective shares of the assets acquired by the household during the marriage is difficult. If the wife has had very little market income, all or most of the household's tangible assets will have been bought with the husband's money. Yet his earning capacity may owe much to her efforts. She may have supported him while he was a student in law school or

158. See Hill v. Hill, 142 P.2d 417, 422 (Cal. 1943) ("[P]ublic policy does not discourage divorce where the relations between husband and wife are such that the legitimate objects of matrimony have been utterly destroyed.").

159. See Theodore F. Haas, The Rationality and Enforceability of Contractual Restrictions on Divorce, 66 N.C. L. REV. 879, 902 (1988) ("Thus, a business partnership is analogous to modern marriage in which each spouse has the right to dissolve at will."); Jane Rutheford, Duty in Divorce: Shared Income as a Path to Equality, 58 FORDHAM L. REV. 539, 554 (1990) ("[C]ourts and legislatures analogize marriage to partnership.”).

160. POSNER, supra note 156, § 5.1, at 161; see also Ira Mark Ellman, The Theory of Alimony, 77 CALIF. L. REV. 1, 35 (1989) ("The complete elimination of alimony probably alone renders the partnership model unacceptable.").

161. POSNER, supra note $156, \S 5.1$, at 161 . 
medical school, reducing her own consumption and also forgoing opportunities to increase her own earning capacity through advanced training. ${ }^{162}$

Despite these inherent difficulties, the courts strive to insure that the marital property is divided both equitably and in a way that " "compensate[s]' both parties to a marriage for their respective contributions." 163

In fact, the very structure of divorce proceedings aims to ensure that the rights and benefits of each former spouse are adequately protected. Two facets of divorce law in particular warrant discussion here: first, the law's refusal to sanction informal or common law divorce, and second, the court's insistence on independently reviewing settlement agreements to ensure that both parties are being treated equitably.

1. The Absence of Common Law Divorce. Although a handful of states permit couples to wed informally, without any requirement that they obtain a marriage license or hold a marriage ceremony, ${ }^{164}$ no state permits such informality when it comes to divorce. Instead, in an attempt to safeguard the economic interests of the divorcing parties, states require strict adherence to both the substantive and procedural dictates of that state's divorce laws. ${ }^{165}$ So while marriage can sometimes be created by informal means, no marriage can be dissolved without the judicial system playing at least some role in the process.

Common law marriage is a means of obtaining the legal protections of marriage without going through the strictures of the formal marriage process. Common law marriage merely requires that the couple intend to be married, have the legal capacity to wed, exchange words with one another to that effect, and, in many states, both cohabitate and hold themselves out to the community as a married couple. ${ }^{166}$ Although this practice was historically justified by

162. Id. $\S 5.3$, at 168 .

163. Ann Laquer Estin, Maintenance, Alimony, and the Rehabilitation of Family Care, 71 N.C. L. REV. 721, 748 (1993).

164. See generally GORAN Lind, COMMON LAW MARRIAGE: A LEGAL INSTITUTION FOR COHABITATION (2008) (describing common law unions that lack the formalities of traditional marriage).

165. See, e.g., Kergosien v. Kergosien, 471 So. 2d 1206, 1210 (Miss. 1985) ("Divorce is a creature of statute ... It is a statutory act and the statutes must be strictly followed as they are in derogation of the common law.").

166. See Cultural Sociology of Divorce: An EnCyClopedia 300 (Robert E. Emery 
the fact that people living in rural, isolated areas of the United States might not have access to the "civil and religious authorities" required for a ceremonial marriage, ${ }^{167}$ it is now justified by a need to protect the parties to the marriage. Common law marriage protects the parties' expectations that their conduct effectuated a valid marriage, thus securing the benefits and protections that flow from marriage. ${ }^{168}$ It also protects "those members of society who can least afford to give up any part of the limited protections the law currently affords them." 169 Specifically, it protects "the poor, women, children, and members of minority groups" 170 who might otherwise be at the mercy of a cohabitating partner who, for a variety of reasons, refuses to engage in a formal marriage ceremony. ${ }^{171}$

In contrast to common law marriage, no state permits couples to dissolve a marriage by informal means. ${ }^{172}$ Nor does any state appear to be moving in that direction, ${ }^{173}$ which is a somewhat telling omission given the increasing amount of control states have given married couples over the terms of their marriage. As Professor Theodore F. Haas explains, "[p]rivate ordering of marital and postmarital relationships generally has been accepted with respect to certain incidents of those relationships - ownership of property and, to a lesser

ed., 2013); LIND, supra note 164, at 187 ("A cornerstone in the Western concept of marriage is the requirement that the parties possess the legal capacity to marry.").

167. PNC Bank Corp. v. Workers' Comp. Appeal Bd., 831 A.2d 1269, 1279 (Pa. Commw. Ct. 2003). As one court noted, "[t]he covered wagon days are over. In this county no person lives, who cannot in some manner easily reach the county courthouse and partake of the beneficence of those who are by law endowed with the privilege authorizing and conducting the marriage ceremony." In re Estate of Soeder, 220 N.E.2d 547, 562 (Ohio Ct. App. 1966).

168. See Kathryn S. Vaughn, The Recent Changes to the Texas Informal Marriage Statute: Limitation or Abolition of Common-Law Marriage?, 28 Hous. L. REV. 1131, 1140-41 (1991) (arguing that common law marriage protects the parties' expectation of marriage).

169. Id. at 1141

170. Id.; see also Cynthia Grant Bowman, A Feminist Proposal To Bring Back Common Law Marriage, 75 OR. L. REV. 709, 779 (1996) (advocating for common law marriage on the basis that "it protects the interests of women, especially poor women and women of color").

171. See Ariela R. Dubler, Wifely Behavior: A Legal History of Acting Married, 100 COLUM. L. REV. 957, 964 (2000) (noting that one of the policies underlying common law marriage is "that the law should protect innocent women from the whims and contrivances of irresponsible or rakish men").

172. See Haas, supra note 159, at 881 n.13 ("[S] uch a method of divorcing is unknown to Anglo-American law."); Raven C. Lidman \& Betsy R. Hollingsworth, The Guardian Ad Litem in Child Custody Cases: The Contours of Our Judicial System Stretched Beyond Recognition, 6 GEO. MASON L. REV. 255, 287 n.156 (1998) ("There is no such thing as 'common law divorce."”).

173. See Haas, supra note 159, at $881 \mathrm{n} .13$ ("There is no readily discernible trend either toward the reinstitution of common law marriage or toward the institution of common law divorce."). 
extent, support. However, divorce itself-the change of marital status-has remained a matter of public rather than private ordering." ${ }^{\prime 174}$ Even common law marriages can only be dissolved by a formal divorce. "If there is a valid common law marriage, it cannot thereafter be dissolved except in the same manner as a valid ceremonial marriage-the parties themselves, for instance, cannot dissolve it by an agreement to do so, or by a denial that it occurred." ${ }^{175}$

The courts are so opposed to the notion of common law divorce that many have outright rejected any argument that would approximate recognition of common law divorce. For instance, in In re Marriage of Brooks, ${ }^{176}$ Harry and Maureen Brooks married in 1950, separated in 1965, and officially divorced in $1978 .{ }^{177}$ During the divorce proceedings, Harry objected to the court's classifying as "marital property" the property he had acquired after their separation. ${ }^{178}$ The court, however, rejected this argument, writing that "Harry's suggestion that the date of the parties' separation should be used as the termination date of Maureen's marital property rights is baseless. For us to hold that a de facto termination extinguishes marital property rights would create, in effect, 'common law divorce."'179 According to the court, "[l]aw and policy will not support such a result." 180

Such cases offer a glimpse into the reasoning behind the law's refusal to sanction common law divorce. Aside from the enormous evidentiary benefit of obtaining a formal divorce decree, public policy demands that divorces play out under the supervision of a court of law to ensure that each spouse's contributions to the marriage are fully taken into account and fairly compensated. As discussed in greater detail below, family law is generally reluctant to allow divorcing couples to make settlement agreements on their own-as they would have to do in a common law divorce-because, "[d]espite the resemblance that marriage bears to a business partnership, the marital relationship is not . . . an unalloyed example of free-market principles." ${ }^{181}$ Courts recognize that people in an emotional

174. Id. at 880 .

175. Chivers v. Couch Motor Lines, Inc., 159 So. 2d 544, 550 (La. 1964).

176. In re Marriage of Brooks, 486 N.E.2d 267 (Ill. App. Ct. 1985).

177. Id. at 269.

178. Id. at 271.

179. Id. at 272.

180. Id.; accord In re Marriage of Morris, 640 N.E.2d 344, 347 (Ill. App. Ct. 1994).

181. PosNer, supra note 156, $\$ 5.2$, at 164; see also Louis E. Wolcher, "The Enchantress" and Karl Polanyi's Social Theory, 51 OHIO ST. L.J. 1243, 1261 (1990) ("Marriage in its typical form is 
relationship are not "dealing at arm's length," so the presence of the court is warranted to help safeguard the economic interests of the two parties. ${ }^{182}$ If we return to the prisoner's dilemma, it becomes clear that states understand that giving couples the option of informal divorce incentivizes behavior that leads to situations where one or both parties is economically harmed. Such harm, in turn, compromises the state's interest in safeguarding the health and wellbeing of its citizens. States therefore refuse to sanction common law divorce, making it more likely that couples who wish to dissolve their marriage will involve the state in that process, even if only to protect their own economic interests.

2. Review of Settlement Agreements. In general, courts view all domestic agreements with some degree of skepticism. ${ }^{183}$ When it comes to prenuptial agreements, for example, courts routinely review them for unconscionability, require the parties to disclose the nature and extent of their assets before entering into such agreements, and may even set aside such agreements when the circumstances of the parties have changed so drastically as to render application of the agreement inequitable. ${ }^{184}$ Thus, although prenuptial agreements "must adhere to the normal rules of contract," 185 such agreements "remain more vulnerable to attack than commercial contracts because of special standards that govern their enforcement."186

Concerned with protecting the rights and benefits of divorcing spouses, courts have treated settlement agreements in a similar fashion. As an initial matter, courts prefer that divorcing couples come to an agreement on their own regarding the terms of the divorce. ${ }^{187}$ After all, if the parties can themselves agree, then the divorce is less likely to be

arguably one of the most emotional and relational, and least rational and individualistic, of all human transactions.").

182. See infra notes 313-19 and accompanying text.

183. See Brian Bix, Domestic Agreements, 35 Hofstra L. Rev. 1753, 1771 (2007) ("The law has always been skeptical of contracts between intimates....").

184. See Brod, supra note 143, at 254, 260.

185. Allison A. Marston, Planning for Love: The Politics of Prenuptial Agreements, 49 STAN. L. REV. 887, 898 (1997).

186. Id.; see also Recent Developments, 104 HARV. L. REV. 1399, 1399 (1991) ("In general, state courts have refused to treat prenuptial agreements like other contracts, and have enforced them only if they meet local tests of procedural and substantive fairness.").

187. Pamela Laufer-Ukeles, Selective Recognition of Gender in the Law: Revaluing the Caretaker Role, 31 HARV. J.L. \& GENDER 1, 14 (2008) ("Generally, courts encourage divorcing couples individually to craft separation agreements regarding the incidents of divorce (except agreements involving child support, visitation and custody)...."); see also UNIF. MARRIAGE AND DivORCE ACT § 306(e) (NAT'L. CONFERENCE OF COMM'R ON UNIF. STATE LAWS 1970). 
acrimonious. Additionally, the final product is more likely to reflect the true preferences of the parties than would an adjudicated result. ${ }^{188}$

Still, courts recognize the possibility of overreaching and even coercion, and do not give couples carte blanche when it comes to such agreements. Instead, "[a]t the final hearing most jurisdictions require the judge to review settlement agreements for unfairness or unconscionability." ${ }^{189}$ As Professor Sally Burnett Sharp explains:

[I]t is commonly said that a settlement agreement, like any other contract, must be free from any fraud, duress, undue influence, or overreaching of any kind. Most states, however, impose as an additional safeguard the requirement that an agreement be submitted to a court for its approval and that it cannot be merged or incorporated into the final decree without such approval. Judicial approval, at least in theory, will be withheld unless the court finds that the proposed agreement is equitable, or fair and reasonable, or not unconscionable. ${ }^{190}$

Although there is some debate about just how meaningful these protections really are ${ }^{191}$ their existence nonetheless points to the law's awareness of the harm that can result from a lack of judicial oversight. As one court wrote, "an agreement in anticipation of divorce is not the same as any ordinary contract. [Although] [p] ublic policy favors parties settling their own disputes in a divorce ... the family court has a statutorily authorized role ... [in] assur[ing] a fair and equitable dissolution of the state-sanctioned institution of marriage." 192

Courts take this role so seriously that, even when both sides are represented by counsel, the court retains the right to set aside a

188. See generally Marc Galanter \& Mia Cahill, "Most Cases Settle”: Judicial Promotion and Regulation of Settlements, 46 STAN. L. REV. 1339 (1994) (advocating a more critical approach for evaluating the merits of settlements).

189. Penelope Eileen Bryan, Women's Freedom To Contract at Divorce: A Mask for Contextual Coercion, 47 BUFF. L. REV. 1153, 1239 (1999).

190. Sally Burnett Sharp, Fairness Standards and Separation Agreements: A Word of Caution on Contractual Freedom, 132 U. PA. L. REV. 1399, 1407 (1984).

191. Eleanor Holmes Norton, Bargaining and the Ethics of Process, 64 N.Y.U. L. REV. 493, 569 (1989) ("R]eview of divorce agreements often has been perfunctory. Evidence of patent misconduct, such as fraud or concealment, is generally necessary to attract judicial intervention."); Sharp, supra note 190, at 1407 (“[J]udicial review requirements as currently applied by courts fail in any event to provide a meaningful review for either substantive or procedural fairness."); see also Bryan, supra note 189, at 1238-39 (noting that "[w] hat review does occur seems directed more to whether the parties voluntarily agreed to the settlement than to the settlement's substance").

192. Pouech v. Pouech, 904 A.2d 70, 77-78 (Vt. 2006). 
settlement agreement that it deems inequitable to one of the parties. For example, in Bellow v. Bellow ${ }^{193}$ the court set aside a settlement agreement that failed to refer to a $\$ 10,000$ account that the husband had withdrawn, incorrectly classified a jointly owned apartment as the separate property of the husband, and estimated the husband's income to be $\$ 30,000$ when it was in fact $\$ 150,000 .{ }^{194}$ In so ruling, the court noted that "[i]n reaching our decision we are aware the plaintiff had the benefit of able counsel all through the proceedings [and] [w]e are reluctant to overturn the property settlement voluntarily entered into .... Nevertheless, we find there is evidence to support the judgment of the trial court," which had determined that the settlement agreement leads to an "inequitable result." 195

Taken together, the absence of common law divorce and the requisite judicial review for settlement agreements reveal that divorce is an essential legal tool for the state's protection of former spouses. Moreover, these mechanisms also serve as an incentive to participate in the formal divorce process in the first place-individuals who question whether they are leaving the marriage with everything to which they are entitled would invoke the protections of the court to obtain greater assurances on that front and an enforceable order to that effect. In other words, that divorce is a legal option provides an incentive to ignore thoughts of an informal settlement and instead elect to pursue a formal divorce in the hopes of achieving a more personally beneficial outcome.

\section{B. Protections for Future Spouses}

Divorce protects subsequent spouses from the ever-present possibility of desertion, which can harm subsequent spouses as much as it does deserted spouses. For while no state permits common law divorce, nothing prevents a married couple from simply going their separate ways without officially divorcing. This option is often dubbed "the poor man's divorce," 196 given its appeal to those for whom a divorce proceeding is simply too costly:

Historically, the cost of lawyers and court fees, the bewildering

193. Bellow v. Bellow, 352 N.E.2d 427 (Ill. App. Ct. 1976).

194. Id. at 429 .

195. Id. at 432 .

196. Sidney B. Jacoby, Legal Aid to the Poor, 53 HARV. L. REV. 940, 957 (1940) (“[D]esertion is called in popular speech the 'poor man's divorce' due to the practical inability of many poor persons to obtain a divorce."). 
jargon of "complaints" and "cross-complaints," the time-consuming and seemingly complex legal process, and the popular association of courts with crime, have served to dissuaded the poor from seeking legal divorce. At the point of breakup it often seems much easier simply to separate-or for the man to desert-than go through the hassles and traumas of legal divorce. ${ }^{197}$

To put it more simply, "owing to strained finances and a lack of legal assistance," some individuals "often forgo divorce and dissolve their marriages informally."198

Given the harms that can befall an individual whose marriage ends without an adjudication of the spouses' respective rights and obligations, desertion is an undesirable way to effectuate separation. ${ }^{199}$ The law therefore actively attempts to encourage formal divorce, ${ }^{200}$ and one of the most powerful incentives provided by the law is the rule that a person can only have one spouse at a time.$^{201}$ Parties may informally separate, but once either of them wishes to remarry, he or she must obtain a divorce from the first spouse. "Going through the formal divorce process is a condition precedent to the taking of a second wife or husband." 202

Despite this requirement, "a significant segment of our society utilizes desertion as a means of dissolving marriages," 203 and some of those individuals go on to marry someone else. This illegal second marriage presents a tangible problem for the subsequent spouses. As one commentator points out, "the real problem develops when ... they decide to remarry and want to make the second marriage work." 204 Without legally dissolving the first marriage, the second marriage is

197. LenORE J. WeItZMAn, THE MARriage Contract: SPOUSES, LOVERS, AND THE LAW 194 (1981) ("Thus common-law divorce has always been most prevalent among poverty subcultures.”).

198. Id. at 206.

199. See Timothy Follett, In re The Marriage of Ramirez: Sex Lies, and California's Annulment for Fraud Based on Fidelity, 43 GOLDEN GATE U. L. REV. 433, 455 (2013) ("[D]ivorce proceedings protect marriage by recognizing that the marriage existed and then enforcing the rights and obligations of the parties that chose to enter into the marriage contract.").

200. See, e.g., Rhonda Wasserman, Parents, Partners, and Personal Jurisdiction, 1995 U. ILL. L. REV. 813, 832 (2000) ("Because wives were dependent upon their husbands for support, abandoned women would have been left destitute without ex parte divorces.").

201. See supra note 28 and accompanying text.

202. Thomas v. LaRosa, 400 S.E.2d 809, 815 (W. Va. 1990).

203. Taylor, supra note 25 , at 479 .

204. WeITZMAN, supra note 197, at 194. 
invalid ${ }^{205}$ rendering the parties to the subsequent marriage bereft of any spousal protections. And while the bigamous party would be exposed to the dangers of potential criminal liability, ${ }^{206}$ it is that party's second spouse who suffers the real harms. "The invalid marriage disqualifies the second spouse from the default protection marriage provides a (legitimate) surviving spouse, while the [first,] lawful marriage simultaneously protects the valid marriage partner's interest and prevents the bigamous partner from profiting from the illegitimacy of the marriage." 207

Given the harms that accrue to subsequent, legally invalid spouses, the courts have developed three doctrines to protect them: the subsequent marriage presumption, the marriage by estoppel doctrine, and the putative spouse doctrine. As will be described in the next sections, each doctrine is used to safeguard the protections that would have naturally accrued had the bigamous spouse obtained a valid divorce prior to the second marriage.

1. Subsequent Marriage Presumption. Suppose that Henry married Catherine but subsequently moved out and married Anne. ${ }^{208}$ Unhappy with Anne, he deserted her and married Jane. At no point does he file for divorce from either Catherine or Anne. Henry then dies, leaving a rather large fortune. Not surprisingly, Catherine, Anne, and Jane all come forward claiming to be Henry's wife. A problem thus arises - who is Henry's legal wife? Many would assume the answer to be Catherine. After all, until he divorced his first wife, all subsequent "marriages" would be void. In most instances, however, the correct response would be just the opposite-Jane would prevail.

Jane would owe her victory to what is frequently described as "the strongest presumption[] in the law" 209 - namely, the subsequent or lastin-time marriage presumption. Using this presumption, courts presume

205. Dorsey v. Dorsey, 66 So. 2d 135, 139 (Ala. 1953) ("A woman can have but one lawful husband living, and so long as he is alive and the marriage bond remains in full force, all her subsequent marriages, whether meretricious or founded in mistake and at the time supposed to be lawful, are utterly null and void.").

206. See supra note 29 and accompanying text.

207. Lynne Marie Kohm, Why Marriage is Still the Best Default in Estate Planning Conflicts, 117 PENn ST. L. ReV. 1219, 1231 (2013).

208. In all the hypotheticals contained in this Article, the parties take their names from those involved in the fascinating history of Henry VIII and his six wives. See generally ALISON WEIR, THE SIX WIVES OF HENRY VIII (1991).

209. Smith v. Heckler, 707 F.2d 1284, 1285 (11th Cir. 1983); see also Vaughan v. Vaughan, 195 Miss. 463, 471 (1943) (describing the presumption as "one of the strongest known to the law"). 
"that any former marriage was terminated by death, annulment, or divorce" 210 and assume that a person's most recent marriage is the one that is legally valid. The burden then shifts to the former spouse to prove that their marriage was never legally terminated. ${ }^{211}$

What might sound like a rather easy burden to meet is nearly impossible. After all, "a prior spouse will only be able to rebut this lastin-time marriage presumption by searching all of the divorce records where the deceased spouse resided-or could have resided-in order to prove that no divorce decree was ever granted to the deceased spouse." 12 As one court described the required burden of proof, "every reasonable possibility of validity must be negatived, and ... the evidence to overcome the presumption of validity of the subsequent marriage must be clear, strong, and satisfactory and so persuasive as to leave no room for reasonable doubt." 213

An illustration of this onerous burden can be found in the 1951 case of United States v. Burns. ${ }^{214}$ Lillie Harris Burns married Elisha Burns in Mississippi in 1928, but after the couple moved to Missouri, Elisha left her for another woman, Rosie Lee Liverson. ${ }^{215}$ Lillie Harris then moved to Arkansas, never divorced Elisha, and likewise never received notice that he had filed for divorce from her. ${ }^{216}$ Nonetheless, Elisha and Rosie Lee married in 1943. ${ }^{217}$ When Elisha died, both women came forward claiming to be Elisha's surviving spouse in order to obtain the proceeds of his insurance policy. ${ }^{218}$ The court applied the subsequent marriage presumption, stating that the burden was on Lillie (as the first-in-time spouse) "to prove by clear and decisive evidence

210. Joseph W. McKnight, Family Law, Husband \& Wife, 49 SMU L. REV. 1015, 1018 n.17 (1996)

211. See Parker v. Am. Lumber Co., 56 S.E.2d 214, 216 (Va. 1949) ("[T]he second marriage is presumed valid; such presumption is stronger than and overcomes the presumption of the continuance of the first marriage, so that a person who attacks a second marriage has the burden of producing evidence of its invalidity.").

212. Peter Nash Swisher \& Melanie Diana Jones, The Last-in-Time Marriage Presumption, 29 FAM. L.Q. 409, 410 n.3 (1995) (emphasis added).

213. Harper v. Dupree, 345 P.2d 644, 647 (Kan. 1959) ("In other words, it is said that the burden of proving that a divorce has not been granted to either party to a former marriage is substantial and is not met by proof of facts from which mere inferences may be drawn.").

214. United States v. Burns, 95 F. Supp. 628 (E.D. Ark. 1951).

215. Id. at 629 .

216. Id.

217. Id. Lillie likewise remarried a man named Fred Hamilton, but several years after their marriage, he learned of Elisha and left Lille. $I d$.

218. Id. 
that neither party had obtained a divorce." ${ }^{219}$ Although the court recognized the difficulty imposed by such a burden, which essentially required Lillie "to prove a negative," 220 it nonetheless ruled that the high burden was necessary "to overcome the sacred and stalwart presumption protecting the marriage state." 221 Lillie attempted to satisfy her burden by producing "certificates from the clerks of counties where Elisha was supposed to have lived since the date of her marriage to him, showing that by proper search of the records no record was found of any divorce granted to either Elisha Burns or Lillie Harris Burns during his lifetime." 222 But unfortunately for Lillie, she neglected to search one particular county. The court pointed out that "it is in evidence that after Elisha left [Lillie] he lived in St. Francis County, Arkansas, and no certificate was furnished for that county." 223 For that reason, Lillie's claim failed, and she was denied the proceeds of Elisha's insurance policy. ${ }^{224}$

In essence, the subsequent marriage presumption operates by presuming a divorce, when in fact, one likely never occurred. There are several policy-based motivations underlying this presumption, the first of which is to protect the family, ${ }^{225}$ particularly the children of the various relationships. For instance, looking back at the earlier hypothetical, assume that Henry had one child each with Catherine, Anne, and Jane. To treat his marriage to Catherine as the only valid marriage would mean that the children borne to Anne and Jane would be considered nonmarital or-to use the outdated, more pejorative term-illegitimate. On the contrary, to assume that each subsequent marriage was instead valid, each child would be considered legitimate. ${ }^{226}$ Because distinctions based on legitimacy have

219. Id. at 630 (citing Mo. Pac. R.R. v. Harris, 120 S.W.2d 695, 696 (Ark. 1938)).

220. Id.; see also Swisher \& Jones, supra note 212, at 430 n.170 ("It is generally recognized that in many fact situations these elements place a heavy, sometimes an impossible, burden on the attacker to prove two negatives - no death and no divorce.").

221. Burns, 95 F. Supp. at 630 .

222. Id. at 629 .

223. Id.

224. Id. at 630 ("Having failed to produce the required quality of evidence she must be deemed to have failed to make good her claim.").

225. See Tatum v. Tatum, 201 F.2d 401, 406 (9th Cir. 1957) (noting that one of the policy rationales for the presumption is "to protect and strengthen the social and moral standards of the community").

226. See, e.g., Fowler v. Tex. Expl. Co., 290 S.W. 818, 822 (Tex. Civ. App. 1926) (noting that the presumption "should always be indulged [but] especially when such presumption is necessary to protect the legitimacy of children"). 
increasingly died away, such protection may seem less important today. ${ }^{227}$ Nonetheless, legitimacy remains one of the historic justifications for the presumption.

A second, more important motivation is the degree to which the subsequent marriage presumption protects the parties' expectations and the subsequent spouses' welfare. The deceased likely considered his most recent spouse his actual spouse, to whom he would confer all the accompanying rights and benefits of marriage. ${ }^{228}$

Last is the states' interest in "protecting apparent spouses in economically vulnerable positions from becoming welfare recipients." ${ }^{229}$ As noted earlier, numerous benefits attend marriage. ${ }^{230}$ Were it not for the subsequent marriage presumption, individuals like Jane would be denied all those protections and benefits simply because she had the misfortune of marrying someone who failed to divorce a previous spouse. And those previous spouses (Catherine and Anne in our hypothetical) are likely much less in need of protection because they have-ostensibly, at least-been living without Henry for some time. ${ }^{231}$

Given these "strong and persuasive underlying public policy rationales," a vast majority of jurisdictions continue to recognize and apply the subsequent marriage protection as a means of safeguarding the protections that would otherwise flow from legal divorce. ${ }^{232}$

2. Marriage by Estoppel. Suppose instead that Henry only had one wife, Catherine, but she was previously married to someone else, Arthur. ${ }^{233}$ Suppose further that, before she even met Henry, Catherine

227. See Swisher \& Jones, supra note 212, at 414.

228. See, e.g., Rainer v. Snider, 369 N.E.2d 666, 669 (Ind. Ct. App. 1977) ("The presumption rests upon strong social policies which give effect to the expectations of the parties."); McClaugherty v. McClaugherty, 21 S.E.2d 761, 765 (Va. 1945) ("While it is true, however, that cohabitation and repute do not constitute marriage, they do constitute strong evidence tending to raise a presumption of marriage, and the burden is on him who denies the marriage to offer countervailing evidence.").

229. See Swisher \& Jones, supra note 212, at 414.

230. See supra notes 146-48 and accompanying text.

231. See RANDy Frances KAndel, FAmily LAw: EsSEnTIAL TERMS And CONCEPTS 27 (2000) ("The first spouse, whether validly divorced or not, has been separated from the decedent socially and financially for an extended time, has survived in other ways, and is less likely to be expecting such benefits.").

232. See Swisher \& Jones, supra note 212, at 414-15 (describing the number of jurisdictions as "overwhelming").

233. Interestingly enough, Henry VIII's first wife, Catherine of Aragon, was indeed previously married to Arthur, Henry VIII's older brother. It was Arthur who was originally heir 
divorced Arthur, but the divorce was invalid for some reason. So when Henry files for divorce from Catherine, she counters that the two were never legally married, citing the fact that her previous marriage to Arthur was never properly dissolved. Many people would likely assume that Catherine's argument would prevail-a person can only have one spouse at a time and Catherine's previous marriage remains legally in effect. Instead, Henry would likely prevail by using the doctrine of marriage by estoppel.

Traditionally, equitable estoppel requires "(1) action or nonaction [by one person] which induces (2) reliance by another (3) to his detriment." ${ }^{234}$ In cases like Catherine's, those elements would rarely be satisfied. To the extent that Catherine's invalid divorce would operate as a detriment to her, it is one that she herself created-Henry played no role. In fact, the only role Henry played was to enter into a purported marriage with Catherine. Traditional equitable estoppel actually allows individuals like Henry to rely on a prior invalid divorce to divest individuals like Catherine of all the rights they thought they had acquired in the subsequent marriage.

Once again recognizing the extreme harm that can result from reliance on an invalid marriage, family law provides a solution: the courts apply equitable estoppel differently when one spouse attempts to rely on a previous, invalid divorce. Marriage by estoppel, as the doctrine has come to be called, "is unlike classic equitable estoppel in that it does not focus solely on whether one party has made a misrepresentation on which the other has reasonably relied." 235 Instead, "[t]he focus is broader and requires a consideration of all of

to the English throne, and he married Catherine when he was just fifteen years of age. When he unexpectedly died just a few months later, Henry became the heir and, like his brother before him, took Catherine for his wife. See generally SEAn CUNNINGHAM, PRINCE ARTHUR: The TUDOR KING WHO NEVER WAS (2016). Even more interesting is the fact that it was this previous marriage that provided Henry with the ammunition to ultimately annul his marriage to Catherine. Specifically, "[s] he was his brother's wife, and, under ecclesiastical law, their sexual relationship was considered incest. After Catherine had undergone numerous miscarriages and stillbirths, Henry became convinced that God was punishing him for his incestuous marriage to her, and he sought an annulment in 1525." CULTURAL SOCIOLOGY OF DivORCE, supra note 166, at 678.

234. Nancy D. Polikoff, This Child Does Have Two Mothers: Redefining Parenthood To Meet the Needs of Children in Lesbian-Mother and Other Nontraditional Families, 78 GEO. L.J. 459, 491 (1990); see also Homer Clark, Estoppel Against Jurisdictional Attack on Decrees of Divorce, 70 YALE L.J. 45, 57 (1960) (defining equitable estoppel as a doctrine in which "one who has taken a position with reference to a transaction and thereby obtained a benefit or brought about a change of position in the other party to the transaction cannot later take an inconsistent position which would prejudice the other party").

235. Lowenschuss v. Lowenschuss, 579 A.2d 377, 381 (Pa. Super. Ct. 1990). 
the circumstances surrounding not only the procurement of the divorce, but also the conduct of the parties thereafter and the effect of a declaration of the invalidity of the divorce on others." ${ }^{236}$ Stated more simply, "[a] person may be precluded from attacking the validity of a foreign divorce decree if, under the circumstances, it would be inequitable for him to do so." 237

Consider the case of Lowenschuss v. Lowenschuss. ${ }^{238}$ There, Pennsylvania resident Beverly Lowenschuss divorced her first husband in 1964 by traveling to Alabama, where she remained only so long as was necessary to obtain a divorce decree. Because she failed to establish residency in Alabama, though, her divorce was invalid. ${ }^{239}$ Not realizing that she had failed to effectuate a legal divorce, Beverly returned to Pennsylvania, where she met and married Fred Lowenschuss. ${ }^{240}$ The couple eventually had four children together. ${ }^{241}$ Fred testified that he learned of Beverly's defective divorce in 1974, but he also testified that, from that point on, they nonetheless "continued to live the same way as before." ${ }^{242}$ In 1981, Beverly filed for divorce, but Fred defended by citing Beverly's invalid Alabama divorce, arguing that, on that basis, he and Beverly were never legally married. ${ }^{243}$ The court refused to allow Fred to even raise the circumstances of Beverly's previous divorce.

Even though Fred was not a party to her prior divorce proceedings, the court ruled that, in light of his conduct, it would be inequitable for him to raise that defense at this late date. Both parties "relied in good faith on the Alabama divorce in marrying each other in 1965 and continued to rely on that divorce at minimum until 1974. . . . Husband conducted himself as a married man for nine years before

236. Id.; see also John De Witt Gregory, Peter N. Swisher \& Robin Fretwell WILSON, UNDERSTANDING FAMILY LAW 39 (2013) ("It is sufficient, in many cases, that a court find only that it would be unfair to let a party take advantage of the legal invalidity of a divorce decree and the invalidity of the subsequent marriage.").

237. RESTATEMENT (SECOND) OF CONFLICT OF LAWS $§ 74$ (AM. LAW INST. 1971).

238. Lowenschuss v. Lowenschuss, 579 A.2d 377 (Pa. Super. Ct. 1990).

239. Id. at 378 ("Wife spent at most two days in Alabama and does not dispute the fact that she has never been a bona fide resident of Alabama.").

240. Id. ("Husband knew that wife was divorced, but denies knowing any of the details concerning how the divorce was procured.").

241. Id.

242. Id. at 379. Fred had commenced his own divorce action in 1974, but subsequently withdrew it when, according to him, he learned of the defective divorce; however, Beverly testified that it was withdrawn because the two reconciled. Id. at 378-79.

243. Id. at 377. 
1974 and after 1974 he continued to live as he had before." ${ }^{244}$ Ultimately, the court found that:

[n]o social purpose will be served by a decision that this marriage simply does not exist and that wife is still the legal wife of her first husband and that her four children were born of an illicit relationship. To hold that husband may now raise this challenge simply in order to avoid the financial obligations of his marriage would be grossly inequitable. ${ }^{245}$

To justify its ruling, the court reiterated the important and protective function of divorce, writing that "a decision which would allow husband to avoid his marital obligations at this late juncture would be completely inconsistent with the Commonwealth's contemporary attitude toward divorce, which is grounded in the application of equitable principles to achieve economic justice and overall fairness between the parties." 246

3. Putative Marriage. Returning to the first hypothetical, assume that Anne-Henry's second wife-defeats the subsequent marriage presumption to the detriment of Jane-Henry's third wife. Were that to happen, one might assume that Jane would be left without any of the protections of marriage, no better off from a property perspective than a longtime roommate. Once again, this assumption would prove incorrect. Family law has one additional weapon in its arsenal to protect a subsequent spouse who learns that she was never in fact legally wed: the putative marriage doctrine..$^{247}$

To understand how it operates, consider the limitations of the two doctrines discussed above. Both the marriage by estoppel doctrine and the subsequent marriage presumption conjure up a valid divorce where, factually, none likely exists. They do so either by presuming the existence of a valid divorce that cannot easily be disproven ${ }^{248}$ or, when faced with evidence of a prior divorce that was clearly invalid, by

244. Id. at 385. The court also noted that there was "no evidence that wife had any knowledge that her Alabama divorce was invalid and an impediment to a valid Pennsylvania marriage when she married husband." Id. Further, "the Alabama judge who granted wife her divorce was later convicted of representing to out of state residents that they could obtain valid Alabama divorces." Id.

245. Id. at 386.

246. Id.

247. See generally Christopher L. Blakesley, The Putative Marriage Doctrine, 60 TuL. L. REV.

1 (1985) (detailing the historical evolution of the doctrine and its basic components).

248. See supra Part III.B.1. 
preventing parties from using that divorce as a means of defeating the validity of their subsequent marriage. ${ }^{249}$ The putative marriage doctrine goes one step further in protecting subsequent spouses, protecting those who entered into a "marriage" in good faith even where the court cannot create a valid divorce to salvage the subsequent marriage.

Essentially, the putative marriage doctrine provides the civil effects of marriage to one who in good faith entered into a marriage that is later revealed to be invalid. ${ }^{250}$ In other words, "[a] putative marriage ... is a marriage which is in reality null, but which allows the civil effects of a valid marriage to flow to the party or parties who contracted it in good faith." ${ }^{251}$ The only requirements parties must meet to avail themselves of this protection is to have had a ceremonial marriage and to have done so in good faith that the marriage would be valid-good faith defined as "ignoran[ce] of the cause which prevents the formation of the marriage or the defects in its celebration which caused its nullity." 252

Like the subsequent marriage presumption and the marriage by estoppel doctrine, the putative marriage doctrine is intended to protect innocent spouses-including mistaken bigamists, who innocently but erroneously believe that they obtained a valid divorce prior to remarrying-and promote equity. As one court explained, "[A] marriage contracted when one spouse is a party to a previously undissolved marriage is absolutely null; however, equity demands that innocent persons not be injured through an innocent relationship." 253 As Professor Christopher Blakesley points out, the primary motivation behind this doctrine is the desire to ensure fairness. "The putative marriage doctrine is a device developed to ameliorate or correct the injustice which would occur if civil effects were not allowed to flow to a party to a null marriage who believes in good faith that he or she is

249. See supra Part.III.B.2.

250. See Monica Hof Wallace, The Pitfalls of a Putative Marriage and the Call for a Putative Divorce, 64 LA. L. REV. 71, 73 (2003) ("The putative marriage rule provides the proverbial bridge to civil effects in the event parties fail in their attempt to contract a valid marriage, believing in good faith they had done so.").

251. Blakesley, supra note 247 , at 6 .

252. Succession of Marinoni, 164 So. 797, 804 (La. 1935) (quoting 1 M. Planiol, Traité ÉLÉMENTAIRE DE DROIT CIVIL, no. 1096 (3d ed.)); see also Saacks v. Saacks, 96-736, p. 6 (La. App. 5 Cir. 1/28/97); 688 So. 2 d 673, 676 (defining "good faith" as "an honest and reasonable belief that the marriage was valid and that no legal impediment to it existed").

253. Lee v. Hunt, 483 F. Supp. 826, 842 (W.D. La. 1978). 
validly married." ${ }^{254}$ Because "[u]nless some protective or corrective measure intercedes, the normal civil effects of marriage simply do not flow from a marriage which is null." 255

The 2004 Nevada case of Williams $v$. Williams is exemplary. ${ }^{256}$ Richard and Marcie Williams married in 1973 and lived together as husband and wife for the next twenty-seven years, at which time Richard learned that Marcie had never divorced her first husband. ${ }^{257}$ As a result, Richard filed an annulment action to declare his marriage to Marcie void. ${ }^{258}$ The case provided Nevada with its first opportunity to adopt the putative spouse doctrine:

We have not previously considered the putative spouse doctrine, but we are persuaded by the rationale of our sister states that public policy supports adopting the doctrine in Nevada. Fairness and equity favor recognizing putative spouses when parties enter into a marriage ceremony in good faith and without knowledge that there is a factual or legal impediment to their marriage. ... As a majority of our sister states have recognized, the sanctity of marriage is not undermined, but rather enhanced, by the recognition of the putative spouse doctrine. We therefore adopt the doctrine in Nevada. ${ }^{259}$

Applying the doctrine to the case at hand, the court had little difficulty finding that a ceremonial marriage had taken place. ${ }^{260}$

A difficulty arose, however, in gauging whether Marcie had entered into the marriage in good faith. Her claim was merely "that in 1971, she ran into [her first husband] at a Reno bus station, where he specifically told her that they were divorced and he was living with

\footnotetext{
254. Blakesley, supra note 247 , at 6.

255. Id. at 4; see also Wallace, supra note 250, at $72-73$ ("By the general rule, parties who do not enter into a valid marriage create no civil contract and therefore are afforded no rights and duties of that marriage.").

256. Williams v. Williams, 97 P.3d 1124 (Nev. 2004) (per curiam).

257. Id. at 1126

258. Id. ("Richard testified that had he known Marcie was still married, he would not have married her.").

259. Id. at 1128. In reaching this conclusion, the court further noted:

[The doctrine does not] conflict with Nevada's policy [of] refusing to recognize common-law marriages or palimony suits [because, in situations involving] the putative spouse doctrine, the parties have actually attempted to enter into a formal relationship with the solemnization of a marriage ceremony, a missing element in common-law marriages and palimony suits. Id.

260. Id. ("The district court found that the parties obtained a license and participated in a marriage ceremony on August 26, 1973, in Verdi, Nevada.").
} 
another woman."261 Richard argued that such reliance was unreasonable given that she had never been served with divorce papers, and, at the very least, she had a duty to inquire further into the existence of the "divorce" before marrying again. ${ }^{262}$ The court rejected Richard's arguments and ruled in Marcie's favor, noting at the outset that "[g]ood faith is presumed" and that "[t]he party asserting lack of good faith has the burden of proving bad faith."263 Ultimately, the court ruled that the lower court was within its discretion in finding that Marcie had entered into the marriage in good faith given that "substantial evidence supports the district court's finding that Marcie did not act unreasonably in relying upon Allmaras' representations. The record reflects no reason for Marcie to have disbelieved him and, thus, no reason to have investigated the truth of his representations."264

In ruling as it did, the court also made note of Marcie's financial circumstances:

During the 27 years that the parties believed themselves to be married, Marcie was a homemaker and a mother. From 1981 to 1999, Marcie was a licensed child-care provider for six children. During that time, she earned $\$ 460$ a week. At trial, Marcie had a certificate of General Educational Development (G.E.D.) and earned $\$ 8.50$ an hour at a retirement home. She was 63 years old and lived with her daughter because she could not afford to live on her own...

... The district court found that Marcie had limited ability to support herself. ${ }^{265}$

Implicit in this recitation is the court's awareness of the degree to which Marcie would be harmed if forced to walk away from a twenty-sevenyear relationship with no property rights flowing from what she believed was a valid marriage. By finding that Marcie was a putative spouse, the property acquired during her marriage to Richard was

261. Id. at 1127 .

262. Id. at 1129

263. Id. at 1128; see also Succession of Zinsel, 360 So. 2d 587, 592 (La. Ct. App. 1978) (“[G]ood faith is presumed to exist in favor of a party claiming to be a putative spouse who, free of her own impediment, enters into the marriage and the burden of proving the lack of good faith is upon the party attacking the marriage.").

264. Williams, 97 P.3d at 1129. The court then noted that "[a]lthough older case law suggests that a party cannot rely on a former spouse's representation of divorce, more recent cases indicate this is just a factor for the judge to consider in determining good faith." Id.

265. Id. at 1127 . 
labeled quasi-community property and divided equally between them. ${ }^{266}$

In sum, when two people enter into a marriage, but one of those individuals is still legally married to someone else, the results can be devastating for the subsequent spouse who later learns that his "marriage"-and all the accompanying protections he thought he enjoyed-never legally existed. The state is likewise harmed because it "becomes responsible for supporting a spouse if the divorce settlement does not provide financial security." 267 The three doctrines discussed above were developed to help avoid such harms. These "alternative constructs and regulations are used to protect vulnerable parties in long-term cohabitant relationships." 268

Most importantly, each of those doctrines derive their effectiveness from the fact that the law currently only allows a person to have one spouse at any given time. As the next section discusses, should that numerical limitation go away, new harms would emerge, and these doctrines would be powerless to stop them.

\section{The EX Ante Costs of LEgALIZING Polygamy}

This Article argues that, even assuming that the right to marry did include plural marriage, the state's interest in promoting divorce among separating couples is nonetheless a compelling justification requiring nothing short of a complete ban on polygamy. As noted in the Introduction, there are times when the law attempts to neutralize the harmful results that can arise from prisoner's dilemmas by discouraging cooperation between "prisoners." The law of divorce is one such example. Specifically, to prevent spouses from cooperating in a scheme wherein they eschew divorce in favor of informal separation, the law provides a number of inducements directed at both parties, increasing the likelihood that at least one of them will defect from any such scheme and instead opt to formally dissolve the marriage. ${ }^{269}$ As explained more fully below, legalizing polygamy would remove one of

266. Id. at 1129-30 ("Community property states that recognize the putative spouse doctrine apply community property principles to the division of property, including determinations of what constitutes community and separate property.... We agree with this reasoning.").

267. Carolyn Counce, Family Law-Cary v. Cary: Antenuptial Agreements Waiving or Limiting Alimony in Tennessee, 27 U. MEM. L. REV. 1041, 1043 (1997).

268. See Pamela Laufer-Ukeles \& Ayelet Blecher-Prigat, Between Function and Form: Towards a Differentiated Model of Functional Parenthood, 20 GEO. MASON L. REV. 419, 453 (2013) (noting alternatives to traditional common law marriage).

269. See infra Part IV.A. 
the strongest incentives - the threat of a bigamy prosecution-for married couples to formally divorce, thus making formal divorce less likely among separating couples and consequently undermining the various protections the law of divorce has been carefully crafted to safeguard.

One might ask why contemporary law should be concerned with polygamy given that the practice of plural marriage is, and always has been, banned throughout the country. The answer is that, regardless of its current legal status, plural marriage nonetheless continues to exist within the United States. ${ }^{270}$ Such marriages are, of course, legally invalid and those who practice polygamy are subject to criminal prosecution. ${ }^{271}$ Nonetheless, the institution has persevered, and some argue that the practice is even growing. ${ }^{272}$ Although the Supreme Court has upheld these prohibitions in the face of First Amendment challenges,${ }^{273}$ it has never had occasion to address whether a right to polygamy exists under the Due Process Clause of the Fourteenth Amendment. Given the recent success of a similar challenge to the states' ban on same-sex marriage ${ }^{274}$ and the fact that, for political reasons, no state is likely to legalize polygamy in the near future, an argument that plural marriage falls within the ambit of the fundamental right to marry is likely the strongest basis at present for reversing the United States' longstanding ban on polygamy.

The problem, however, is that even if one could successfully convince the Court that the right to marry likewise includes the right to polygamy, the states' prohibitions on the practice would nonetheless survive a constitutional challenge so long as a state could demonstrate that, first, it has a "compelling interest" to justify the restrictions and, second, that those restrictions do not "unnecessarily burden or restrict constitutionally protected activity." 275 It is the interest in requiring and promoting divorce among separating couples that provides the requisite state interest in justifying an absolute prohibition on polygamy. After all, as discussed more fully below, even attempts to distinguish polygamy from bigamy would fail to safeguard this

270. See supra Part I.

271. See supra note 29 and accompanying text.

272. See supra note 75 and accompanying text.

273. See supra notes 57-62 and accompanying text.

274. See supra notes 123-38 and accompanying text.

275. See Storer v. Brown, 415 U.S. 724, 760 (1974) (Brennan, J., dissenting) (describing strict scrutiny). 
overriding interest on the part of the state. ${ }^{276}$

Although other scholars have discussed the impacts of legalizing polygamy, ${ }^{277}$ they have done so by focusing exclusively on how the practice would impact those who affirmatively seek to engage in plural marriage as that practice is traditionally understood. In contrast, this Article focuses, not on polygamists, but on sequential bigamists - that is, those who will marry more than once but never with the intent of having more than one spouse at a time-and the ex ante consequences that the legalization of polygamy would have on their marriages. Looking at polygamy through this lens makes much clearer the dangers to the state and the necessity of an absolute prohibition.

In developing this argument, this Part first explores the harms that would accrue if polygamy were legalized, focusing specifically on the economic harms that legal polygamy would pose to spouses, both current and subsequent. This Part then addresses some of the possible distinctions a state might draw to permit "traditional" polygamy yet prohibit sequential bigamy, arguing that none of those legislative distinctions would adequately safeguard the state's interest in protecting spouses.

\section{A. Legalized Polygamy Undermines the States' Compelling Interest in Promoting Divorce Among Separating Spouses}

As discussed earlier, formal divorce furthers the state's interest in safeguarding the economic well-being of its citizens, including those who are exiting a marriage and those who may enter into a marriage with someone who was married before. ${ }^{278}$ For those reasons, the state has a strong interest in assuring that all are sufficiently incentivized to formally divorce and not simply desert the marriage. More specifically, the state seeks assurances that the separation adequately and fairly provides for the financial needs of each party, that the parties are taking from the marriage that to which they are entitled, and that any children of the marriage are being fully supported and cared for in a way that is in their best interests. ${ }^{279}$ And when it comes to the poor, the

276. Requiring that all parties consent to a polygamous marriage, for example, would provide no assurances that such consent was not coercively obtained. See infra Part IV.B.

277. See supra note 37 and accompanying text.

278. See supra Part III.

279. See Stephen Cretney, The Law and the Family - Time for Divorce?, 32 COMMON L. WORLD REV. 101, 115 (2003) (describing "the arguments for judicial involvement in divorce proceedings" as including "that the interests of the children need to be protected, that couples need to be properly informed about the consequences of their actions, and that they may benefit 
state's interest is particularly acute - the states' general parens patriae role of protecting "all individuals of the state who cannot protect themselves" is coupled with the degree to which divorce can further erode an individual's financial stability. ${ }^{280}$

Attempting to promote divorce, however, is not an easy job for the state. Even in the most amicable of separations, divorce is unpleasant. It is emotionally taxing, potentially stigmatizing within one's community, and, most significantly, incredibly expensive. Evidence suggests that among poorer Americans, divorce may be so expensive that it is essentially unattainable. ${ }^{281}$ Thus, the incentives that the state provides are paramount. After all, beyond those who cannot afford to divorce, the question remains - why would any couple elect to divorce when they could save themselves a lot of trouble and expense by simply going their separate ways?

The answer lies in the number of legal incentives that the state has designed to encourage formal divorce. To begin with, starting a new life costs money, so those who leave a marriage do not want to do so empty handed; they would prefer to depart with as close to what they put into the marriage as they can. Divorce is helpful in that regard as it offers an adversarial proceeding with a judge who will independently review any agreement the parties reach. For those reasons, divorcedespite its less attractive qualities - can seem like the best option when it comes to helping the parties obtain a better and more equitable result. Relatedly, many people will view divorce as an attractive option because, after the marriage is formally dissolved, their ex-spouse cannot make a claim on any property that they acquire in the future.

Still, such economic incentives are by themselves insufficient to encourage many people who want to permanently separate to formally divorce. For those couples who cannot afford a divorce, the propertybased incentives to divorce might not be meaningful. ${ }^{282}$ The message that formal divorce proceedings safeguard property interests, for example, is not likely to compel married couples who do not own any meaningful property. And even couples who can afford to divorce

from advice and counseling about their personal relationships").

280. See Griffith, supra note 143, at 331 (noting that an analysis for the state's parens patriae power extends beyond children).

281. See supra note 24 and accompanying text.

282. See Danaya C. Wright, Untying the Knot: An Analysis of the English Divorce and Matrimonial Causes Court Records, 1858-1866, 38 U. RICH. L. REV. 903, 928-29 (2004) (hypothesizing that a low number of separation petitions filed by wives indicates an economic inability to continue the suit). 
might determine that an informal separation agreement would be more economically advantageous than a formal divorce.

Of course, as noted earlier, ${ }^{283}$ the law cannot always rely exclusively on one variety of incentives when it comes to dealing with prisoner's dilemmas. Instead, "[t]he Hobbesian Leviathan that we live under needs not only the hammer of contract to uphold promises, but also the hammer of mandatory regulation in criminal law, tort law, contract law, and other areas of law, regulation that says, 'Thou shalt not.""284 Laws prohibiting bigamy provide that necessary second incentive. When married couples separate, the parties know they cannot legally marry another person until they first divorce their previous spouse. This requirement lures even those couples that decide to informally separate to divorce court once either of them wants to remarry. And while it is true that bigamy prosecutions remain relatively rare, ${ }^{285}$ one must presume that most individuals would rather not take the chance of being prosecuted for such a crime. This is particularly true because bigamy is a crime that carries with it quite a bit of social stigma, even for mere allegations. ${ }^{286}$ That a conviction is unlikely is probably little encouragement to those who might publicly face such charges.

Aside the threat of criminal prosecution, the current rule that no person may have more than one spouse at any one time also offers other, more practical incentives. Specifically, the law offers a plethora of rights and benefits reserved exclusively for those who are legally

283. See supra notes 12-13, 15-18 and accompanying text.

284. Wayne Eastman, Ideology and Formality: The Eternal Golden Snarl, 29 CONN. L. REV. 849, 852 (1997); see also Lynn A. Stout, Judges as Altruistic Hierarchs, 43 WM. \& MARY L. REV. $1605,1617 \mathrm{n} .38$ (2002) ("[M] ost people seem to try to stay within the constraints of tort law and criminal law, even when a cold calculation of costs and benefits suggests they could profit from negligent or criminal behavior."). For instance, the penalties that exist for failing to pay taxes are necessary in part because "[n]o one wants to pay taxes because the benefits are so diffuse and the costs are so direct. But everyone may be better off if each person has to pay so that each share the benefits of schools, roads, and other collective goods." ROBERT AXELROD, THE EVOLUTION OF COOPERATION 133 (rev. ed. 2006).

285. See supra note 19 and accompanying text.

286. See, e.g., Christopher R. Leslie, Creating Criminals: The Injuries Inflicted by “Unenforced” Sodomy Laws, 35 HARV. C.R.-C.L. L. REV. 103, 103 (2000) (listing various harms that flow from unenforced sodomy laws). As Professor Leslie argues, "[a] criminal law, though not enforced through prosecutions, may still affect society." Id. Of particular relevance here is Professor Leslie's point that unenforced laws impose "the stigma of criminality." Id. at 112 (quoting John D'Emilio, Sexual Politics, SeXual Communities: The Making of a HomoseXuAl MinORITY IN THE UNITED STATES, 1940-1970, at 14 (1983)). Presumably, most non-polygamists would not only be motivated to divorce by the fear of a bigamy prosecution, but also the stigma that would come from simply being accused of bigamy. 
married. ${ }^{287}$ The flip side of reserving these benefits for legal spouses is that one who thinks himself married and thus relies on those protections would be even more harmed if it is later revealed that the marriage was invalid. ${ }^{288}$ Accordingly, even if criminal prohibitions on bigamy are insufficient to steer married individuals into divorce court before marrying a second spouse, the financial risk to which they are exposing their subsequent spouse provides an even more powerful incentive.

If polygamy were to become legal, however, the current prohibitions on having more than one spouse would go away, taking with them the incentives those laws provide for formal divorce. Instead, unhappily married couples who decide to forgo divorce could simply remarry without the fear of being prosecuted for bigamy or having a subsequent marriage be declared void. Accordingly, any ruling that requires states to recognize polygamy would cause an increase in plural marriage-both purposeful plural marriage and sequential polygamy, in which a person is legally married to multiple people as a result of deciding not to get formally divorced from "previous" spouses - and the resulting injury would be significant. As discussed below, for those people who elect to become sequential polygamists, those harms would be particularly acute, harming both current and subsequent spouses and, in the process, undermining the states' substantial "interest in protecting the financial interests of the parties at divorce" 289

1. Harms to Initial Spouses. For current spouses, the most significant harms would result from the loss of oversight by the court. In other words, for those couples that elect to permanently separate but not divorce, the state would lose its opportunity to ensure that the couple ends their marriage on terms that are fair and equitable to both parties. As discussed earlier, the law does not permit common law divorce, and courts will review any settlement agreement between divorcing parties for fairness even during formal divorces. ${ }^{290}$ These requirements stem from the law's awareness that, when left to their own devices, divorcing couples may not act in their own economic self-

287. See supra notes $146-48$ and accompanying text.

288. As outlined earlier, the law has fashioned a number of doctrines designed to avoid such results. See supra Part III.B. But those protections are not guaranteed or necessarily sufficient to fully protect the subsequent spouse. See infra Part IV.A.2.

289. In re Marriage of Wisth, 754 N.W.2d 254, 254 (2008).

290. See supra Part III.A. 
interest, which creates too great a possibility that agreements between the parties could be the product of coercion or fraud. ${ }^{291}$

The removal of the bigamy bar could lead to de facto common law divorce wherein separating couples would only have, at best, whatever protections given them in settlement agreements. If the state has no way of approving these agreements, divorcing parties can be left in a precarious financial situation without the state's knowledge or protection. Hardest hit would be those who were already, while married, facing financial difficulty ${ }^{292}$ Moreover, even fair and equitable settlement agreements would be less secure without the enforceability of a formal divorce decree..$^{293}$

It is true, of course, that simply because a couple does not immediately divorce does not mean they will never divorce-some simply wait. Such delays can and will take place regardless of how the law treats plural marriage. But if polygamy is legalized, such a delay could be quite costly because one of the spouses could legally remarry before divorcing their first spouse.

Consider the following hypothetical: Henry marries Catherine and the two acquire significant marital property. Henry then deserts Catherine and marries Anne, and they too acquire significant marital property. With no prohibition on bigamy, Henry's actions are entirely legal. Ten years after Henry's marriage to Anne, Catherine files for divorce. Despite the delay, Catherine will now receive her day in court, alleviating some of the concerns raised by plural marriage. ${ }^{294}$ Unfortunately, new problems arise. First, there is the question of who Catherine must divorce - is she simply divorcing Henry or is this now a polygamous marriage amongst all three parties, which would require her to file for divorce from both Henry and Anne? ${ }^{295}$ Once that issue is

291. See Donald WitTMAn, ECONOMic Foundations OF LAW AND ORGANIZATION 218 (2006) ("[T]here is typically a greater emotional bond between a married couple than between business partners. The conflict between two people who love each other is likely to be less than the conflict between two people with greater self interest.").

292. See supra notes 24-27 and accompanying text.

293. See, e.g., Unif. MARriage AND DivorCe ACt $\S 306(\mathrm{e})$ (NAT'L. Conference of COMM'RS ON UNIF. STATE LAWS, amended 1973) ("Terms of the agreement set forth in the decree are enforceable by all remedies available for enforcement of a judgment, including contempt, and are enforceable as contract terms.").

294. Namely, the concerns about whether couples come to fair and equitable agreements when they divorce.

295. For a thoughtful discussion of such practical concerns, see Adrienne D. Davis, Regulating Polygamy: Intimacy, Default Rules, and Bargaining for Equality, 110 COLUM. L. REV. 1955, 1959 (2010) (contrasting "polygamy with aspects of partnership law to derive a set of default rules that 
resolved, the court and the parties must contend with the question of what property Catherine is entitled to. She could only be entitled to the property that she and Henry acquired before his marriage to Anne. But that approach is unsatisfactory given that her marriage to Henry remained legally in effect after Henry married Anne. Traditionally, any property acquired by the spouses after marriage and before the entry of the divorce decree is subject to division at divorce. ${ }^{296}$ So Catherine could also be entitled to a share of all of the property acquired by Henry prior to their formal divorce. But this approach only gives her a fractionalized interest in the property that he acquired after marrying Anne because Anne, of course, also has an interest in her marital property with Henry. In other words, rather than having a one-half interest in all the property acquired by her or Henry during the entirety of their marriage, Catherine would only have a one-third interest in any of the property acquired after Henry married Anne. ${ }^{297}$ Even if one could devise a system for dividing the property equitably, there remains the challenge of simply ascertaining when all the property was acquired. ${ }^{298}$

Further, this dilemma can cause a perverse incentive-if Catherine maintains a claim to a percentage of the property that Henry acquires with his subsequent spouse, Catherine might be inclined to wait as long as possible to file for divorce. This would again undermine the states' interest in encouraging prompt divorces. ${ }^{299}$ Thus, were polygamy legalized, not only would there be a concern for married couples who refuse to divorce before marrying others, but there could also be financial complications resulting from divorce proceedings that are delayed until one spouse has legally married another, third party.

2. Harms to Subsequent Spouses. Legalized polygamy would not only expose initial spouses to economic harm, but would likewise imperil the economic interests of subsequent spouses by eviscerating the law's current protections for those individuals. As the last

might accommodate polygamy's marital multiplicity").

296. See supra notes $179-80$ and accompanying text.

297. All of this would again be compounded by the complications associated with who exactly Catherine is having to divorce-Henry by himself, or Henry and Anne together.

298. Not to mention the problems stemming from such complications as commingling and transmutation. See generally J. Thomas Oldham, Tracing, Commingling, and Transmutation, 23 FAM. L.Q. 219 (1989) (exploring the issues inherent in separating individual property from marital property).

299. See Taylor, supra note 25 , at 467 ("Certainly, there are important reasons for encouraging compliance with legal requirements for such dissolution.”). 
hypothetical illustrates, subsequent spouses would be harmed by any system in which couples lose the incentive to divorce. Subsequent spouses would always be at risk of having to split what they believe to be their exclusive marital property with someone to whom their spouse had previously been married, thus subjecting the subsequent spouse to reduced financial protection. In some ways, that would be an advantage over the current system, which only allows a person to have one legal spouse at a time. Under current law, a subsequent, bigamous marriage would be void, providing subsequent spouses with no interest whatsoever in marital property. ${ }^{300}$ As noted earlier, however, the law has adopted a number of doctrines to protect against this harm: the subsequent marriage presumption, the marriage by estoppel doctrine, and the putative spouse doctrine. ${ }^{301}$ Legalizing polygamy, however, would essentially eviscerate these protections, putting subsequent spouses in a much more precarious financial situation than current law permits.

For instance, the subsequent marriage presumption is driven by the current legal reality that a person can only have one spouse, and thus presumes the last-in-time spouse to be a person's legal spouse. ${ }^{302}$ Without a numerical limit on spouses, however, the presumption is no longer needed. In other words, if a person can have more than one spouse, there is no need for a presumption designed to reduce the number of possible spouses to just one. Instead, a woman who married three men in succession would be considered to have three husbands, each having a claim to her estate. If the polygamy is sequential rather than concurrent-meaning the wife never intended to have multiple husbands but never got a divorce from earlier husbands - the result of having the husbands share equally could be particularly harmful to the final husband as, in all likelihood, he would be the most dependent on the property in question, the first two husbands having already moved on and built lives elsewhere. ${ }^{303}$

Marriage by estoppel would be equally unnecessary because a previously botched divorce would no longer be a bar to the subsequent marriage's validity. ${ }^{304}$ There would be less incentive for either party to

300. See Ransford C. Pyle \& Carol M. Bast, Foundations of law: Cases, COMMENTARY AND ETHICS 354 (6th ed. 2016) (defining bigamy as "a crime" and noting that "a bigamous marriage is void").

301. See supra Part III.B.

302. See supra Part III.B.1.

303. See supra note 231 and accompanying text.

304. See supra Part III.B.2. 
a divorce to bring up the fact that one of them failed to properly end a previous marriage. After all, doing so could potentially bring an additional person (that is, the previous spouse) into the proceedings, resulting in the original parties' receiving a smaller percentage of the marital estate. ${ }^{305}$

The putative spouse doctrine is the only one of the three that would retain some utility given that, regardless of the legality of plural marriage, there would still be situations in which a person mistakenly, but in good faith, thought he was married to another. ${ }^{306}$ The doctrine would probably be used much less frequently, though, because it is typically employed in cases where the subsequent marriage was invalid due to one of the parties never having divorced their previous spousea situation that would no longer be an obstacle to the validity of the subsequent marriage were polygamy to be legalized.

In sum, formal, legal divorce protects not only the two former spouses but also the subsequent spouses of those individuals. To more fully incentivize formal divorce between separating couples, however, the states rely on their ability to criminalize bigamy - a tool they would be forced to forfeit should polygamy become a constitutional right. In the absence of any criminal penalty, separating couples would be more likely to choose mutual desertion over divorce, risking not only their own economic well-being, but that of their subsequent spouses as well.

\section{B. A Complete Ban is Necessary To Safeguard the States' Interest}

As discussed above, legalizing polygamy could very well prompt a number of serial monogamists to become sequential polygamists, thus exposing both the spouses and the state to significant harm. ${ }^{307}$ Much of that analysis, however, is premised on the assumption that the right to engage in polygamy would come with no more restrictions than currently attend marriage. Some may argue that the proper limitations could greatly ameliorate many of the concerns outlined in this Article, so that - if polygamy falls within the fundamental right to marry - the states' objections to plural marriage would be insufficient to justify a complete ban. As the Court has made clear, if a state wishes to restrict a fundamental right, it must do more than simply prove that it possesses a substantial interest; the state must prove that its approach to safeguarding that interest does not encroach the constitutional right

305. See supra notes 296-98 and accompanying text.

306. See supra Part III.B.3.

307. See supra Part IV.A. 
any more than necessary. ${ }^{308}$ In both Zablocki and Turner, for instance, the Court struck down state restrictions on marriage because, according to the Court, those prohibitions were much broader than were necessary to achieve their stated purpose. ${ }^{309}$

Accordingly, the question arises as to whether states could impose limitations on the right to polygamous marriage that would distinguish polygamy from bigamy so as to permit the former (i.e., concurrent polygamy) yet prohibit the latter (i.e., sequential polygamy). ${ }^{310}$ In other words, perhaps a state could craft its laws in such a way that polygamy is available to those who affirmatively wish to engage in that precise practice, yet unavailable to others who attempt to use polygamy merely as an excuse to avoid divorce proceedings prior to marrying a subsequent spouse. There are two possible ways that the law could effectuate that discrete goal. First, the law could condition validity on the requirement that parties to an existing marriage must each consent to the addition of a subsequent spouse. Second, if adding spouses over time is problematic, the law could also require that only unmarried individuals enter into a polygamous marriage, essentially resulting in the requirement that all parties to a plural marriage must wed in one single ceremony. Ultimately, both options fail to safeguard the states' substantial interest in protecting their citizens.

1. Gradual Polygamy with Consent. Returning to the parties in the previous hypotheticals, assume that Henry marries Catherine and the two later decide to expand into a polygamous marriage. The two meet Anne, and everyone agrees that Anne should join the marriage. In order to accommodate such situations while also minimizing the potential for sequential polygamy, the law could condition legal sanction of a polygamous marriage on the consent of all parties to the marriage. Unfortunately, though, the ex ante consequences of this scheme are problematic.

Allowing a married couple to agree to add another spouse to the marriage gives rise to concerns about duress and coercion. One way to understand these concerns is to examine courts' existing suspicion of postnuptial agreements, which itself parallels courts' skepticism of

308. See supra note 107 and accompanying text.

309. See supra notes 109, 116-17 and accompanying text.

310. As noted earlier, some have already attempted to distinguish the two terms. See supra note 31 and accompanying text. The issue becomes, however, whether the state could adopt meaningful distinctions that would permit one practice while prohibiting the other. 
settlement ${ }^{311}$ and prenuptial agreements. ${ }^{312}$ Like a prenuptial agreement, a postnuptial agreement "is an agreement that determines a couple's rights and obligations upon divorce," ${ }^{313}$ but the difference is that the parties enter into the agreement after already having been married. ${ }^{314}$ Given the timing, the courts are quite suspicious of such agreements-even more so than they are of prenuptial and settlement agreements. As one court explained:

A [postnuptial] agreement stands on a different footing from both a premarital and a separation agreement. Before marriage, the parties have greater freedom to reject an unsatisfactory premarital contract. ...

A separation agreement, in turn, is negotiated when a marriage has failed and the spouses "intend a permanent separation or marital dissolution." ... The family unit will no longer be kept intact, and the parties may look to their own future economic interests. . . The circumstances surrounding [postnuptial] agreements in contrast are "pregnant with the opportunity for one party to use the threat of dissolution 'to bargain themselves into positions of advantage."”315

Stated differently, there is a fear that a person may threaten to divorce his spouse unless she agrees to sign a postnuptial agreement and the spouse-determined to preserve her marriage, or at least the benefits flowing from that marriage-may be willing to agree to almost anything, including an agreement that is contrary to her best interests. ${ }^{316}$ After all, "[w]hile it is lawful and not against public policy for husband and wife to enter into such contracts, ... they are not dealing with each other as strangers at arm's length." 317

311. See supra Part III.A.2.

312. See supra notes $184-86$ and accompanying text.

313. Sean Hannon Williams, Postnuptial Agreements, 2007 WIS. L. REV. 827, 828 (2007).

314. See Sharon Thompson, Prenuptial Agreements AND the Presumption of Free CHOICE: IsSUES OF POWER IN THEORY AND PRACTICE 91 (2015) (distinguishing "unmarried parties entering prenups" from "married parties entering postnuptial agreements").

315. Ansin v. Craven-Ansin, 929 N.E.2d 955, 962-63 (Mass. 2010) (footnote omitted) (quoting PRINCIPLES OF THE LAW OF FAMILY DISSOLUTION: ANALYSIS AND RECOMMENDATIONS $\S$ 7.01(1)(c), at 946 (AM. LAW INST. 2002); then quoting Pacelli v. Pacelli, 725 A.2d 56, 62 (N.J. Super. Ct. App. Div. 1999)).

316. See Amy L. Wax, Bargaining in the Shadow of the Market: Is There a Future for Egalitarian Marriage?, 84 VA. L. REV. 509, 603-04 (1998) (discussing how "divorce threat" may prompt one spouse to strike a "disadvantageous bargain out of a self-interested fear of defection").

317. In re Estate of Gab, 364 N.W.2d 924, 926 (S.D. 1985) (quoting Keith v. Keith, 156 N.W. 910, 911 (S.D. 1916)). 
For the foregoing reasons, postnuptial agreements are thus subject to increased scrutiny ${ }^{318}$ As with prenuptial and settlement agreements, courts review postnuptial agreements closely for fairness and equitability. As one court explained:

Although we agree with the defendant that principles of contract law generally apply in determining the enforceability of a postnuptial agreement, we conclude that postnuptial agreements are subject to special scrutiny and the terms of such agreements must be both fair and equitable at the time of execution and not unconscionable at the time of dissolution. ${ }^{319}$

The concerns that animate the courts' treatment of postnuptial agreements mirror the issues presented by allowing spouses to consent to plural marriage and should militate against allowing married couples to agree to add additional spouses to an existing marriage. For true polygamists who desire an active plural marriage, these concerns may be minimal, but concerns are much more grave for sequential bigamists. Consider an individual who previously separated from his spouse but now wishes to remarry. If polygamy were permitted with the permission of the current spouse, divorce is not necessary to enable the "nonpolygamist" to remarry; instead, he simply has to get his existing spouse to consent. That consent could be acquired through negotiation, although perhaps to the detriment of the first spouse. As the courts are concerned with the bargaining chips used to secure a postnuptial agreement, then, they should likewise be concerned with those used to secure an agreement to add an additional spouse to an existing marriage.

Again, in a legal scheme that allows polygamy with the consent of existing spouses, plural marriage would be available to all citizens, including purposefully polygamous couples and sequentially bigamous couples. The latter, however, could use this option simply to avoid divorce and any resulting financial liabilities. Compare the following hypothetical to the one that began this section: Henry marries Catherine, but later decides he would prefer to have Anne as his wife. Catherine is in poor health and is worried that a divorce will leave her without health insurance, which she receives through Henry's

318. Id. at 925 .

319. Bedrick v. Bedrick, 17 A.3d 17, 23 (Conn. 2011); see also THOMPSON, supra note 314, at 91 ("“ $[\mathrm{M}]$ arital property agreements entered into by spouses (for example postnuptial or separation agreements) are subjected to a much higher level of scrutiny [given that] the parties are not ordinary business partners."). 
employer as his spouse. Henry, concerned about the financial implications of divorcing Catherine, tells her that, if she consents to his marriage to Anne, he need not divorce Catherine and she can continue to enjoy his health benefits. He further agrees to rent an apartment for her and to give her a small allowance each month. Though Catherine would have received significantly more as part of a divorce action, she agrees to Henry's terms. Catherine is accordingly harmed by accepting Henry's offer in lieu of filing for divorce. Further, as noted earlier, should she later change her mind and file for divorce, Anne is now also a legal spouse to the marriage and, as such, would likely have some claim to at least some of the marital property, thus resulting in a diminution of Catherine's share. ${ }^{320}$

So while consent may seem a good way to mitigate some of the concerns over plural marriage, those who have no interest in true polygamy could nonetheless take advantage of the consent provision to evade the divorce requirement. Spouses in Catherine's position would be once again exposed to the potential for extreme financial harm. Thus, when considering the prisoner's dilemma that can arise in the marital context, the law must be mindful of not only the coercion that exists between the two prisoners and the state, but also the coercion that might arise between two "prisoners" who, unlike those in the traditional hypothetical, are allowed to communicate with one another. ${ }^{321}$

Of course, simply because a court should be skeptical of certain kinds of agreements does not mean that those agreements should be illegal. Courts are skeptical of postnuptial agreements, but most states still permit couples to enter into them. ${ }^{322}$ In theory, states could wait to grant a plural marriage license until the consent agreement has been carefully reviewed for coercion and duress, but two problems still remain. First, there is the basic question of whether any polygamous marriage is truly consensual. ${ }^{323}$ Second, even if a court could discern

\footnotetext{
320. See supra notes $296-98$ and accompanying text. One could perhaps argue that the awareness of these resulting penalties would provide new incentives to divorce, but "[f]rustration of an individual's reasonable economic expectations, which will often result in increasing the already crowded welfare rolls, is not the most appropriate method" of incentivizing divorce. Taylor, supra note 25 , at 467 . Given the states' interest in safeguarding the economic security of their citizens, this seems an insufficient protection.

321. See Susan S. Kuo \& Benjamin Means, Collective Coercion, 57 B.C. L. REV. 1599, 161011 (2016) (describing the prisoner's dilemma as a collective coercion problem).

322. See supra notes 313-19.

323. See Davis, supra note 295, at 2008 (recognizing "the difficulty of discerning consent and the fear of duress or other more subtle forms of coercion"); Laurie Shrage, Polygamy, Privacy,
} 
whether a polygamy agreement was truly consensual, such adjudication would typically not happen until some indeterminate time in the future - the point at which one of the original signatories raises lack of consent as a defense. With premarital and postmarital agreements, for example, a court generally is not called upon to determine their validity until one of the parties has died or the couple is divorcing. The same would be true of a postmarital polygamy agreement - there would likely be no question until one of the parties sought to either enforce the agreement or have it declared invalid. By then, enough time would have potentially passed that sorting out the property interests of the multiple parties would be enormously difficult, if not impossible. ${ }^{324}$ After all, the parties to the marriage may have joined at various times and via various polygamy agreements some valid and some not-with the result that some members of the purported plural marriage are legally married to one, but not all, of the individuals comprising the intended group. And, of course, for those who attempted to join the marriage by way of a polygamy agreement that was subsequently found to be coercive, their entry into the "marriage" would presumably be invalid, leaving them without the vital protections of state marriage law.

2. Instant and Complete Polygamy. States could also permit polygamy on the condition that polygamous marriages can only be entered into by people who are currently single. In other words, the law would require all parties to the plural marriage to be married at one time, in a single wedding ceremony. Thus, returning to our hypothetical, if Henry wants to be married simultaneously to both Catherine and Anne, then instead of adding Anne at a later date, all three parties would have to be currently unmarried and would have to wed at the same time. Doing so would help ameliorate-although certainly not eradicate - the concern that a spouse could be coerced into adding another spouse to an existing marriage. Nonetheless, this alternative solution is also problematic.

As an initial matter, most polygamists would likely consider this requirement incompatible with the traditional practice of polygamy.

and Equality, in After Marriage: Rethinking Marital Relationships 160, 178 n.28 (Elizabeth Brake ed., 2016) (conceding that, when it comes to polygamy, "judging genuine consent is likely to be difficult").

324. Of course, even if the polygamous marriage were upheld, the question of how property would be distributed at divorce is far from certain. See Davis, supra note 295, at 1990 (noting that, with polygamy, "the division of spousal property at divorce will be uncertain"). 
Typically, "polygamists do not present themselves as a complete(d) 'group' when they marry, but rather contemplate adding spouses serially." 325

Beyond this practical concern, a requirement that polygamous marriage can only be sanctioned if the parties marry in a single mass ceremony would likely result in polygamists adopting one of two responses, both of which pose dangerous consequences. First, current spouses would simply divorce and remarry whenever they wanted to add an additional spouse. For instance, if Henry were married to Catherine but wanted to add Anne to the marriage, he and Catherine would first need to divorce and then enter into a new marriage involving all three spouses. Given the complexities and time commitment involved in divorce proceedings, it is doubtful many couples would elect to go to all that trouble each time a new spouse was added. More importantly, as discussed earlier, states only wish to promote divorce as an alternative to desertion. ${ }^{326}$ States would prefer for couples who want to be married to maintain that status, ${ }^{327}$ any divorce, even if for a short period of time, leaves the parties without the protections of marriage, exposing them to potential harm for as long as they remain unmarried, which is especially dangerous if they are unable to remarry as planned. ${ }^{328}$

Given the complexity and time commitment involved in divorce proceedings, individuals seeking to create a polygamous marriage would likely wait until all, or at least most, of the desired spouses had been identified and assembled before entering into a legal polygamous marriage. This approach presents a new, but even more significant, harm: the earlier partners would have to wait some time before getting

325. Id. at 2007. Therefore, polygamous unions complicate the traditional notion of when a marriage begins and ends. Id. at 1989. Spouses are usually added serially to polygamous marriages for financial reasons: at the start of a marriage, there is likely some uncertainty about how many spouses the marriage can support, but as the family's wealth grows over time, so too does the ability to support additional spouses. See Witte, supra note 65, at 18 . Additionally, in many cultures, as the original parties to the marriage age, younger wives are added to replace the lost fertility of older wives. Bennion, supra note 75, at 104

326. See supra note 158 and accompanying text.

327. See Mark Strasser, Family, Same-Sex Unions, and the Law, in Routledge Handbook OF FAMILY LAW AND POLICY 45, 59 (John Eekelaar \& Rob George eds., 2014) (noting the states' interest in the "continuation of marriage").

328. This outcome of this hypothetical situation-that the law incentivizes temporary divorce-has really occurred as a byproduct of tax law. See Daniel J. Lathrope, State-Defined Marital Status: Its Future as an Operative Tax Factor, 17 U.C. DAVIS L. REV. 257, 263 (1983) ("Temporary divorces have been undertaken for tax reasons and temporary marriages have been suggested as a tax planning strategy for the unmarried."). 
married and would be without the benefits and protections afforded by legal marriage for that interim period. Again, this puts those individuals at risk should something happen that ultimately prevents them from ever marrying. Ultimately, this result undermines policies a state may have established to incentivize individuals to marry promptly in order to protect their financial security. ${ }^{329}$

A requirement that any polygamous marriage take place all at once is, at best, likely unworkable and, at worst, an incentive to delay marriage until all the eventual spouses are assembled. Such a delaywhich, should the anticipated marriage never take place, would be eternal-can prove devastating to those who spent years in a relationship devoid of the legal safeguards marriage affords. After all, marriage offers much greater protections to those who are financially dependent on an intimate partner-as those in many polygamous relationships tend to $\mathrm{be}^{330}$ - than mere cohabitation. $^{331}$

Clearly, perverse incentives arise from both possible accommodations that states could make to simultaneously permit purposeful concurrent polygamy and prohibit sequential bigamy. These possible accommodations contravene individuals' best interests and the interests of the state. For purposes of satisfying strict scrutiny, then, a complete ban on polygamy is already narrowly tailored. Any attempt to carve out an exception for those who truly wish to engage in concurrent polygamy has too many attendant detriments to make it an actual solution.

329. See Kohm, supra note 207, at 1246 ("Without marriage, those who live together until death do not receive these automatic estate-planning benefits and are left vulnerable to a great deal of problems.").

330. See Janet Bennion, History, Culture, and Variability of Mormon Schismatic Groups, in Modern Polygamy in the United States: Historical, Cultural, AND Legal Issues 101, 113 (Cardell K. Jacobson \& Lara Burton eds., 2011) (describing women within the FLDS community as being "isolated, financially dependent, [and] uneducated").

331. Elizabeth S. Scott, Domestic Partnerships, Implied Contracts, and Law Reform, in RECONCEIVING THE FAMILY: CRITIQUE ON THE AMERICAN LAW INSTITUTE'S PRINCIPLES OF THE LAW OF FAMILY DisSOLUTION 331, 332 (Robin Fretwell Wilson ed., 2006) ("[I]nformal unions ... provide uncertain protection to financially dependent family members because the right to a share of property and support is legally established only after the relationship ends. In contrast, marriage is a status based on registration under which rights and obligations attach at the outset with the exchange of vows."). 


\section{CONCLUSION}

In light of society's increasing acceptance of nontraditional families, ${ }^{332}$ polygamy is "no longer relegated to the hidden cultish confines of southern border towns and western desert wastelands." 333 This change in perception, coupled with the legalization of same sex marriage, has brought to light the question whether, under the Due Process Clause of the Fourteenth Amendment, polygamy might likewise fall within the fundamental right to marriage. This Article argues, however, that the answer to that question is largely irrelevant. The crucial issue is instead whether-even if polygamy were included within that right-the states nonetheless have a compelling justification for continuing their refusal to recognize plural marriage. This Article answers that in the affirmative: yes, states do have such an interest, and it is the promotion of divorce. Not the promotion of divorce at the expense of marriage, but the promotion of divorce over the alternative of desertion.

The state's interest in protecting families and individuals' financial interests forces it to both encourage marriage and, should those marriages end, incentivize formal divorce. But legalizing polygamy deprives the state of one of its most powerful incentives for divorce: the prohibition on being married to more than one person at a time and the subsequent inability to remarry without first divorcing an existing spouse. Without that incentive, separating couples will face a full-fledged prisoner's dilemma between electing for formal divorce and simply going their separate ways. More specifically, if polygamy becomes legal, remarriage while still legally married to someone else likewise becomes permissible. In such a society, spouses might-in light of the costs associated with divorce-be more tempted to simply end their marriages informally, to the great detriment of not only the parties to that marriage but those whom the parties may subsequently wed. Particularly at risk here are the poor, who are much less

332. Marissa J. Holob, Respecting Commitment: A Proposal to Prevent Legal Barriers from Obstructing the Effectuation of Intestate Goals, 85 CORNELL L. REV. 1492, 1510 (2000) (noting the "growing acceptance and proliferation of nontraditional families"); see also Elizabeth S. Scott \& Robert E. Scott, From Contract to Status: Collaboration and the Evolution of Novel Family Relationships, 115 COLUM. L. REV. 293, 297 (2015) ("Some observers suggest that even polygamous relationships are becoming 'normalized,' pointing to the popularity of the television series Big Love and Sister Wives.").

333. BENNION, supra note 75 , at 3 . 
susceptible to the other, property-based incentives to divorce. To protect those vulnerable parties who need the protections guaranteed by formal marriage and, correspondingly, formal divorce, the states thus have a compelling interest in continuing to prohibit polygamy in any form. 